\title{
Venetoclax imparts distinct cell death sensitivity and adaptivity patterns in T cells
}

\author{
Lindsey M. Ludwig ${ }^{1}$, Katrina M. Hawley ${ }^{1}$, David B. Banks (iD ${ }^{1,2}$, Anika T. Thomas-Toth ${ }^{1}$, Bruce R. Blazar ${ }^{3}$, Megan E. McNerney (D) ${ }^{1,4}$, \\ Joel D. Leverson ${ }^{5}$ and James L. LaBelle iD ${ }^{1 凶}$
}

(c) The Author(s) 2021

BH3 mimetics are increasingly used as anti-cancer therapeutics either alone or in conjunction with other chemotherapies. However, mounting evidence has also demonstrated that $\mathrm{BH} 3$ mimetics modulate varied amounts of apoptotic signaling in healthy immune populations. In order to maximize their clinical potential, it will be essential to understand how $\mathrm{BH} 3$ mimetics affect discrete immune populations and to determine how BH3 mimetic pressure causes immune system adaptation. Here we focus on the BCL-2 specific inhibitor venetoclax (ABT-199) and its effects following short-term and long-term BCL-2 blockade on T cell subsets. Seven day "short-term" ex vivo and in vivo BCL-2 inhibition led to divergent cell death sensitivity patterns in $\mathrm{CD}^{+} \mathrm{T}$ cells, $\mathrm{CD} 4^{+} \mathrm{T}$ cells, and Tregs resulting in shifting of global T cell populations towards a more memory $T$ cell state with increased expression of BCL-2, BCL- $\mathrm{X}_{\mathrm{L}}$, and $\mathrm{MCL}-1$. However, twenty-eight day "long-term" BCL-2 blockade following T cell-depleted bone marrow transplantation did not lead to changes in the global T cell landscape. Despite the lack of changes in T cell proportions, animals treated with venetoclax developed CD8 ${ }^{+}$and $\mathrm{CD}^{+}$ $\mathrm{T}$ cells with high levels of $\mathrm{BCL}-2$ and were more resistant to apoptotic stimuli following expansion post-transplant. Further, we demonstrate through RNA profiling that T cells adapt while under BCL-2 blockade post-transplant and develop a more activated genotype. Taken together, these data emphasize the importance of evaluating how $\mathrm{BH} 3$ mimetics affect the immune system in different treatment modalities and disease contexts and suggest that venetoclax should be further explored as an immunomodulatory compound.

Cell Death and Disease (2021)12:1005; https://doi.org/10.1038/s41419-021-04285-4

\section{INTRODUCTION}

While the clinical use of $\mathrm{BH} 3$ mimetics expands against a myriad of cancers [1, 2], little is known about how these compounds affect healthy immune cells [3-5]. A growing body of evidence demonstrates that leukocytes are affected by $\mathrm{BH} 3$ mimetics, at doses equivalent to or lower to those typically used in the context of cancer therapy [5-7]. Our goal in this study was to gain a greater understanding of how surviving immune cells adapt to venetoclax, a $\mathrm{BH} 3$ mimetic specific for $\mathrm{BCL}-2$, with a particular focus on $T$ cells whose apoptotic dependency varies depending on lineage and effector function [8-10].

We previously found that $\mathrm{CD}^{+}$and $\mathrm{CD}^{+}{ }^{+} \mathrm{T}$ cells adapt differently to the loss of BIM, the dominant pro-apoptotic BH3only protein in $T$ cells [11]. Herein we aimed to determine how therapeutic BCL-2 blockade, rather than deletion of its major BH3only binding partner, alters the T cell compartment. We found that $\mathrm{CD}^{+}, \mathrm{CD}^{+}$, and regulatory (Treg) $\mathrm{T}$ cells have disparate cell death sensitivities to venetoclax at baseline and developed varying antiapoptotic protein levels and cell death resistance when expanded in the presence of venetoclax. In vivo, as a whole, $\mathrm{CD}^{+} \mathrm{T}$ cells were most sensitive to short-term venetoclax treatment while Tregs were most resistant. T cell death patterns reflected their activation state, with naïve $T$ cells being more sensitive than memory cells, supporting other recent pre-clinical observations in the context of anti-tumor T cell responses [4]. However, this was not the case for long-term treatment through $T$ cell engraftment following autologous bone marrow transplantation. In this setting, donor-derived T cells overcame BCL-2 blockade to normalize their overall ratios. However, despite a normal appearing phenotypic repertoire, venetoclax resulted in altered anti-apoptotic protein levels and increased cell death resistance to a number of apoptotic stimuli. Surprisingly, venetoclax altered the mRNA expression profile of naive $\mathrm{CD}^{+}$and $\mathrm{CD}^{+} \mathrm{T}$ cells posttransplant towards an "activated-like" state particularly through the upregulation of Jak-STAT and downregulation of MAPK and FoxO signaling pathways. Overall, these data expand our understanding of $\mathrm{T}$ cell acclimation or adaptivity in response to $\mathrm{BCL}-2$ targeting, which may have important implications for the expanded clinical use of venetoclax and other $\mathrm{BH} 3$ mimetics.

\section{MATERIALS AND METHODS}

Animals

B6.Cg-Foxp3 ${ }^{\text {tm2Tch }} / \mathrm{J}$ (FOXP3-IRES-GFP) [12] mice were gifts from Maciej Lesniak, M.D. CD45.1 C57BL/6 and WT (CD45.2) C57BL/6 mice were purchased from The Jackson Labs. Compete blood counts were measured from the peripheral blood of animals using the IDEXX Procyte DX

\footnotetext{
${ }^{1}$ Department of Pediatrics, Section of Hematology/Oncology, University of Chicago, Chicago, IL, USA. ${ }^{2}$ Medical Scientist Training Program, University of Chicago, Chicago, IL, USA. ${ }^{3}$ Department of Pediatrics, Division of Blood and Marrow Transplantation, University of Minnesota, Minneapolis, MN, USA. ${ }^{4}$ Department of Pathology, University of Chicago, Chicago, IL, USA. ${ }^{5}$ AbbVie Inc., North Chicago, IL, USA. ${ }^{凶}$ email: jlabelle@peds.bsd.uchicago.edu Edited by Marco Herold
} 
Hematology Analyzer (IDEXX Laboratories, Westbrook, ME). Animal experiments were approved by and performed in accordance with the guidelines and regulations set forth by the Institutional Animal Care and Use Committee of the University of Chicago.

\section{Cell sorting and flow cytometric analysis}

Single cell suspensions were generated as previously described [13]. Sorted populations used for analysis were $\geq 97 \%$ pure. In all cases, Tregs were sorted and analyzed separately from conventional $\mathrm{CD}^{+} \mathrm{T}$ cells by virtue of their expression of GFP and also confirmed by intracellular expression of FOXP3. A full list of antibodies used for immune cell phenotyping can be found in the supplementary information. Intracellular protein staining was performed with the Fixation/Permeabilization kit (eBioscience, San Diego, CA) per the manufacturer's protocol. Cells were stained with FOXP3-APC(FJK-16s), BCL-2-PE(3F11), BIM-PE(C34C5), BCL- $\mathrm{X}_{\mathrm{L}^{-}}$ $P E(54 H 6)$, and MCL-1-PE(D2W9E). Intracellular flow cytometric detection of $\mathrm{BCL}-2$ family proteins was performed as previously described [14]. Samples were analyzed at the University of Chicago Flow Cytometry Core using a LSRII (BD, Franklin Lakes, NJ) or FACSAria (BD). Data analysis was performed using FlowJo (Tree Star, BD).

\section{T cell stimulation, expansion, and BH3 profiling}

$\mathrm{CD}^{+} \mathrm{T}$ cells, $\mathrm{CD}^{+}{ }^{+} \mathrm{FOXP}^{-}{ }^{-} \mathrm{T}$ cells $\left(\mathrm{CD} 4^{+} \mathrm{T}\right.$ cells), and $\mathrm{CD} 4^{+} \mathrm{FOXP}^{+} \mathrm{GFP}^{+}$ $\mathrm{T}$ cells (Tregs) were cultured as previously described [11] and expanded using CD3/CD28 Dynabeads (Life Technologies, Carlsbad, CA) at a 1:1 bead: cell ratio and $500 \mathrm{U} / \mathrm{mL}$ of recombinant IL-2 (Prometheus Therapeutics \& Diagnostics, San Diego, CA) $\left(\mathrm{CD}^{+}\right.$and $\mathrm{CD}^{+} \mathrm{T}$ cells) or with a 3.5:1 bead: cell ratio and 2,000 U/mL IL- 2 (Tregs). Cells were treated with DMSO (vehicle) or $500 \mathrm{nM}$ venetoclax (AbbVie, North Chicago, IL) daily for five days after reaching logarithmic growth and $>95 \%$ viable (day 3 ). $\mathrm{BH} 3$ profiling was performed as previously described [11]. \% Depolarization was calculated using the following formula: $\%$ Depolarization $=(1-$ (sample$\mathrm{FCCP}) /(\mathrm{DMSO}-\mathrm{FCCP})) \times 100$.

\section{Long-term venetoclax treatment}

CD45. $1^{+}$C57BL/6 recipient mice were conditioned using total body gamma irradiation (Cesium-137) at a fractionated dose of 2x 550 cGy separated by $3 \mathrm{~h}$ ( $1100 \mathrm{cGy}$ total). $24 \mathrm{~h}$ later, mice were transplanted intravenously with $2 \times 10^{6} \mathrm{~T}$ cell-depleted (TCD) bone marrow cells harvested from the femurs and tibia of CD45.2 $2^{+}$FOXP3-IRES-GFP donor mice as previously described [15]. TCD was performed using anti-CD3 mAb coated magnetic beads (MACS separation, Miltenyi, Bergisch Gladbach, Germany). Venetoclax was administered via oral gavage at doses of $25 \mathrm{mg} / \mathrm{kg}, 50 \mathrm{mg} / \mathrm{kg}$, or $100 \mathrm{mg} / \mathrm{kg}$ as previously described [13, 16, 17].

\section{T cell viability measurement}

T cells were transferred to $96-$ well round bottom plates (Denville, South Plainfield, NJ) at a density of $5 \times 10^{4} \mathrm{~T}$ cells/well (sorted T cells) or $2 \times 10^{5}$ splenocytes/well (following transplantation) and treated with increasing concentrations of venetoclax. Cells were cultured in media alone (CDMEM, cytokine deprivation), $1 \mu \mathrm{g} / \mathrm{mL}$ ionomycin, $4 \mathrm{ng} / \mathrm{mL}$ PMA, $1 \mu \mathrm{M}$ etoposide, $250 \mathrm{nM}$ SAHA/vorinostat, and $50 \mathrm{nM}$ staurosporin. Following $24 \mathrm{~h}$ incubation, cell death was assessed using Annexin V-APC (Life Technologies) and propidium iodide (Life Technologies) as previously reported [18].

\section{Reverse transcription and quantitative PCR}

Cells were lysed with Trizol (Life Technologies) and mRNA extracted using the Direct-zol RNA MiniPrep kit (Zymo, Irvine, CA). mRNA concentration and purity were assessed using a DeNovix DS-11 spectrophotometer and reverse transcription performed using the Superscript III first strand synthesis reverse transcription kit (Invitrogen, Carlsbad, CA) per the manufacturer's guidelines. Reverse transcription and quantitative PCR was performed using TaqMan Master Mix and Gene Expression Probes (Applied Biosystems, Foster City, CA) as detailed in the supplementary information. Samples were run on the 7500 Fast Real-Time PCR System (Applied Biosystems). Data was analyzed with the ExpressionSuite software using the $\triangle \triangle C T$ method with UBC as the housekeeping gene and untreated or unstimulated $\mathrm{T}$ cells for the reference samples.

\section{RNA-seq}

Library preparation and sequencing were performed by the University of Chicago Genomics Facility. 30 million, paired end, 100 bp reads for each sample were generated using the NovaSeq6000 (Illumina, San Diego, CA). Alignment to the murine genome (mm10) was performed using HISAT2. Differential expression analysis was performed using EdgeR, and data was filtered to exclude genes with counts per million (CPM) $<2$ in 3 or more samples [19]. Gene set enrichment analysis was performed as described previously [20]. Significantly upregulated and downregulated genes $(p<$ 0.01 ) were analyzed separately for enrichment of KEGG pathways using the DAVID bioinformatics platform with an FDR threshold of $<0.05$ [21, 22].

\section{Statistical analysis}

A one-way ANOVA test was used to evaluate statistically significant changes for increasing doses of venetoclax. For all other comparisons, an unpaired Student's $t$ test was performed and data are expressed as the means \pm SEM. All in vivo treatment experiments were performed a minimum of three separate times. Cells collected from mice were analyzed separately (i.e. not pooled) thereby allowing for biological replicates. Plots were created using Prism (GraphPad Software, La Jolla, CA, USA). Statistical significance was defined as ${ }^{*} p<0.05,{ }^{* *} p<0.01,{ }^{* * *} p<0.001,{ }^{* * *} p<0.0001$.

\section{RESULTS}

Ex vivo expansion in the presence of venetoclax distinctly alters cell death resistance in different $\mathbf{T}$ cell subtypes

To first determine if venetoclax-induced T cell-specific "adaptive" differences, we measured sensitivity to venetoclax in freshly isolated cells ex vivo. $\mathrm{CD}^{+}$and $\mathrm{CD}^{+}{ }^{+} \mathrm{T}$ cells showed similar baseline sensitivities to venetoclax ( $\mathrm{EC}_{50} 40 \mathrm{nM}$ and $68 \mathrm{nM}$ respectively) while Tregs were $2.5-4 \mathrm{x}$ more resistant $\left(\mathrm{EC}_{50} 169 \mathrm{nM}\right)$, similar to other recent reports (Fig. 1A) $[4,8,23]$. Following expansion, $\mathrm{CD}^{+}$and $\mathrm{CD}^{+} \mathrm{T}$ cells became $\sim 50 \mathrm{x}$ fold $\left(\mathrm{EC}_{50} 2,020 \mathrm{nM}\right)$ and $\sim 10 \mathrm{x}$ fold $\left(\mathrm{EC}_{50}\right.$ $611 \mathrm{nM}$ ) more resistant to venetoclax respectively while Tregs had no change (Fig. 1a). However, Tregs expanded in the presence of BCL-2 blockade were $50 \mathrm{x}$ fold more resistant to subsequent venetoclax challenge $\left(\mathrm{EC}_{50} 7020 \mathrm{nM}\right)$ followed by $\mathrm{CD}^{+}{ }^{+} \mathrm{T}$ cells $(4 \mathrm{x}$ fold, $\mathrm{EC}_{50} 2440 \mathrm{nM}$ ) and $\mathrm{CD}^{+} \mathrm{T}$ cells $\left(1.4 \mathrm{x}\right.$ fold, $\mathrm{EC}_{50} 2870 \mathrm{nM}$ ) (Fig. 1A). Venetoclax did not alter the overt "effector memory" phenotype of any expanded T cell subset (Fig. S1).

We next examined if the changes in sensitivity to venetoclax were reflective of differences in anti-apoptotic expression. As predicted, all $\mathrm{T}$ cell subsets significantly upregulated the main $B C L-2$ family regulators of $T$ cell survival, $B C L-2, B C L-X_{L}, M C L-1$, and BIM following expansion (Figs. $1 B, C$ and S2) $[7,11,24,25]$. Stimulation and IL-2 are known to increase expression of BCL-2 and $B C L-X_{L}[26,27]$. Interestingly however, venetoclax treatment led to an even greater upregulation of anti-apoptotic proteins (Figs. 1B, D and S2). BCL-2 family mRNA expression changes following expansion were initially greater in $\mathrm{CD} 8^{+}$and $\mathrm{CD} 4^{+} \mathrm{T}$ compared to Tregs, but venetoclax blunted this while promoting increased expression in Tregs (Fig. S3). The relative levels of $B C l-2$, $B C l-x l, M c l-1, B i m, B a x$, and Bak in all $\mathrm{T}$ cells and treatments underscored their importance in $\mathrm{T}$ cell apoptotic regulation (Fig. S3C-E) [10, 23, 28-30].

We next sought to determine if the presence of venetoclax during expansion induced different anti-apoptotic dependencies in T cells. $\mathrm{CD}^{+} \mathrm{T}$ cells expanded in the presence of venetoclax, still presumably bound to $B C L-2$, continued to rely on $B C L-2$ while $\mathrm{CD}^{+}{ }^{+} \mathrm{T}$ cell and Treg mitochondrial depolarization increased in response to NOXA and $\mathrm{HRK} B \mathrm{BH} 3$ domains, reflecting increased reliance on $\mathrm{MCL}-1$ and $B C L-X_{L}$ respectively (Fig. $1 E$ ). Overall, these results suggest that, at least ex vivo, Tregs and $\mathrm{CD}^{+}{ }^{+} \mathrm{T}$ cells are less dependent on $\mathrm{BCL}-2$ at baseline and are more able to alter their anti-apoptotic dependencies when BCL-2 is blocked compared to $\mathrm{CD}^{+} \mathrm{T}$ cells.

\section{$\mathrm{CD8}^{+} \mathbf{T}$ cells are highly sensitive to venetoclax in vivo, while} Tregs are relatively resistant

To determine if $\mathrm{T}$ cells have similar sensitivities under homeostatic conditions in vivo, mice were treated with increasing doses of venetoclax daily for 7 days. Treatment was universally well 
A
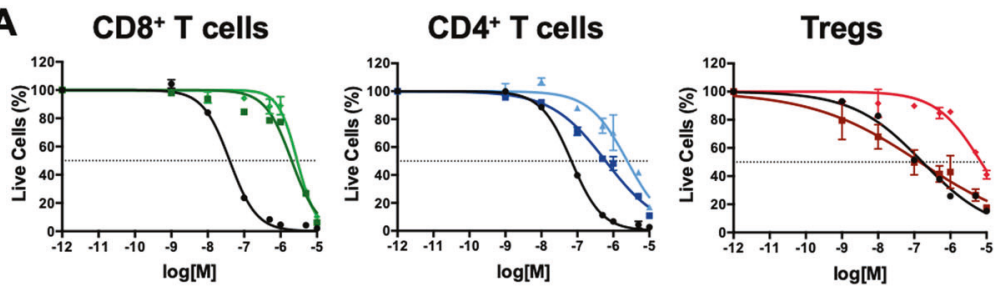

\begin{tabular}{|l|l|l|l|}
\hline $\mathrm{EC}_{50}$ & Unstimulated & Stimulated & $\begin{array}{l}\text { Stimulated }+ \\
\text { ABT-199 }\end{array}$ \\
\hline $\mathrm{CD}^{+} T$ cells & $40 \mathrm{nM} \pm 0.040$ & $\begin{array}{l}2,020 \mathrm{nM} \pm \\
0.05\end{array}$ & $\begin{array}{l}2,870 \mathrm{nM} \pm \\
0.03\end{array}$ \\
\hline $\mathrm{CD4}+T$ cells & $68 \mathrm{nM} \pm 0.02$ & $611 \mathrm{nM} \pm 0.04$ & $\begin{array}{l}2,440 \mathrm{nM} \pm \\
0.06\end{array}$ \\
\hline Tregs & $169 \mathrm{nM} \pm 0.07$ & $142 \mathrm{nM} \pm 0.14$ & $\begin{array}{l}7,020 \mathrm{nM} \pm \\
0.07\end{array}$ \\
\hline
\end{tabular}

B

BCL-2

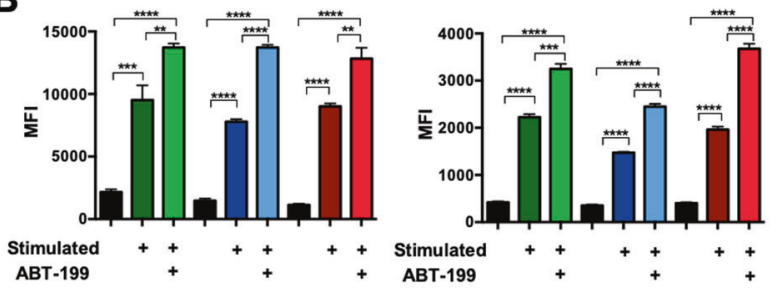

C

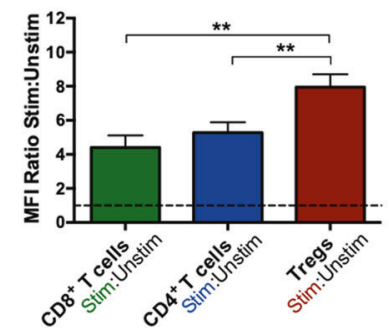

D

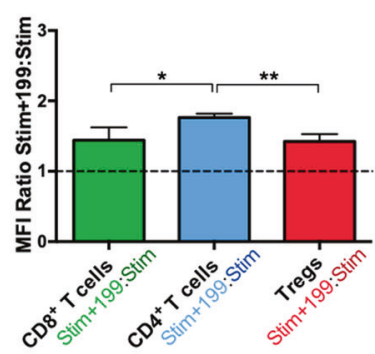

E

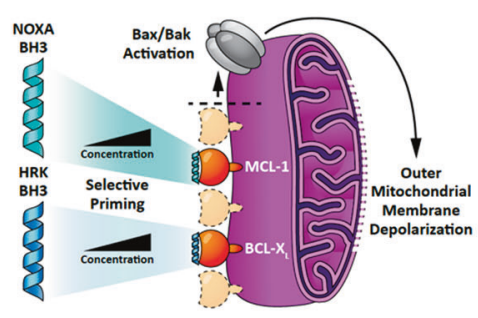

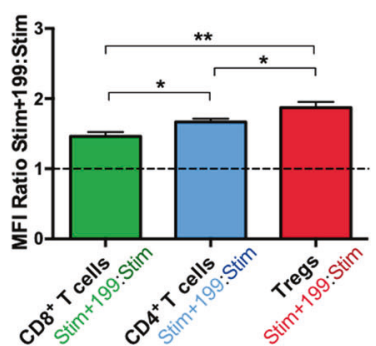

$\mathrm{CD}^{+} \mathrm{T}$ cells
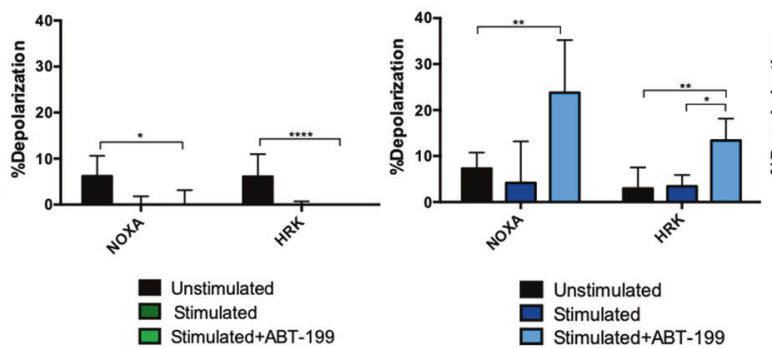

MCL-1

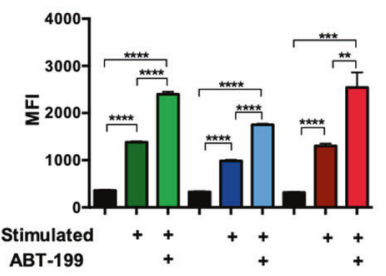

BIM

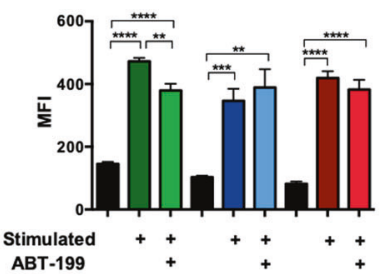

MCL-1

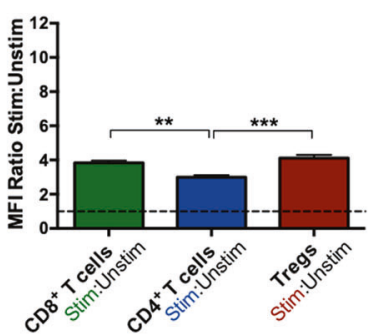

MCL-1

BIM

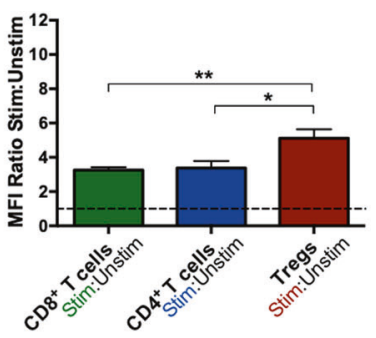

BIM
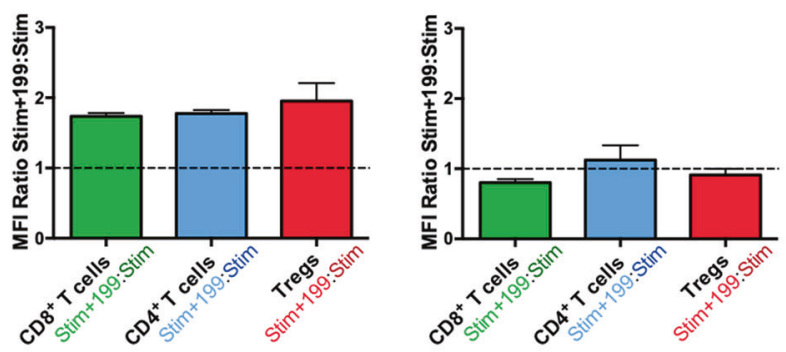

Tregs

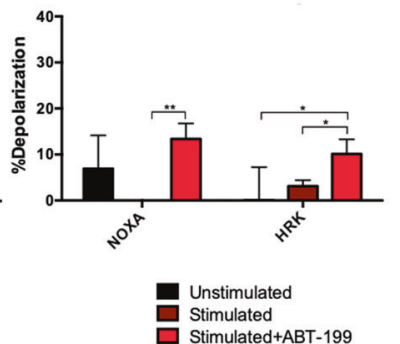

Fig. 1 Ex vivo stimulation and expansion of $\mathrm{CDB}^{+} \mathrm{T}$ cells, $\mathrm{CD4}^{+} \mathrm{T}$ cells, and Tregs alone or in the setting of $\mathrm{BCL}^{-2}$ blockade results in divergent cell death resistance and BCL-2 family protein expression. A Cell death of CD8 ${ }^{+} \mathrm{T}$ cells, CD4 ${ }^{+} \mathrm{T}$ cells, and Tregs treated with venetoclax directly following isolation and after stimulation/expansion alone or in the presence of venetoclax. B BCL-2 family protein levels of unstimulated and stimulated/expanded T cells alone or in the presence of venetoclax. C Ratios of BCL-2 family protein levels in stimulated/ expanded T cells compared to unstimulated and $\mathbf{D}$ between stimulated/expanded in the presence of venetoclax compared to stimulated/ expanded alone. E BH3 profiling of T cells using peptides specific for MCL-1 (NOXA) and BCL-X (HRK) to determine shifts in anti-apoptotic dependencies. Schematic of BH3-peptide specificity and ability to induce mitochondrial outer membrane permeabilization (MOMP) is shown on the left-hand side. Data represented in black represents treatment of cells prior to stimulation. Colored data (CD8 ${ }^{+} \mathrm{T}_{\text {cells }}$ in green, $\mathrm{CD} 4^{+}$ $\mathrm{T}$ cells in blue, and Tregs in red) represent treatment following stimulation (dark green, blue, and red) or following stimulation in the presence of venetoclax (light green, blue, and red). Data is representative of three independent replicates. Data represented as means \pm SEM. ${ }^{*} p<0.05$, ${ }^{* *} p<0.01,{ }^{* * *} p<0.001,{ }^{* * * *} p<0.0001$. 
A

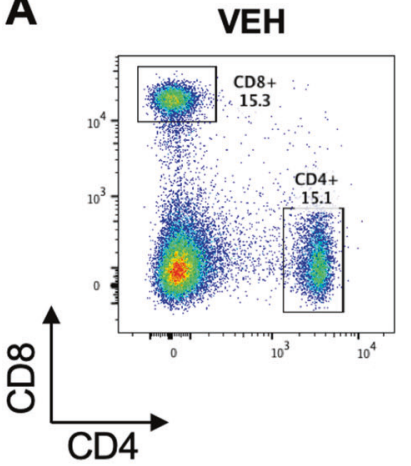

B

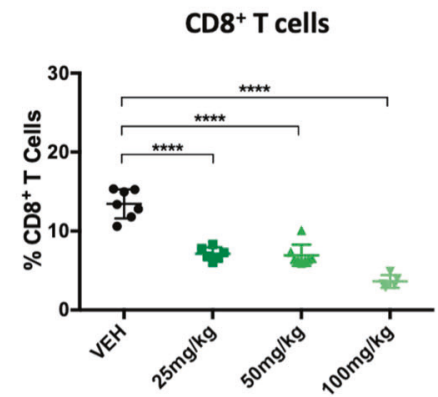

C

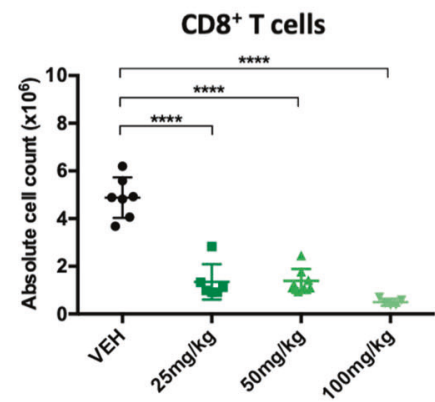

$100 \mathrm{mg} / \mathrm{kg}$

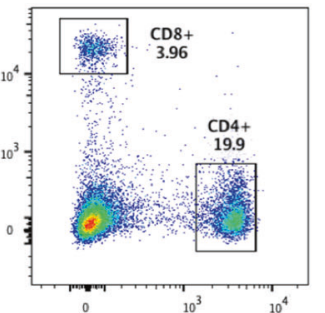

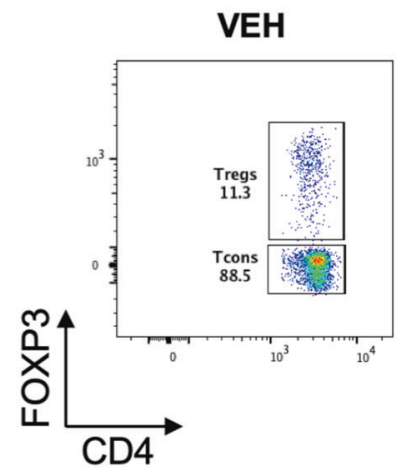

$100 \mathrm{mg} / \mathrm{kg}$

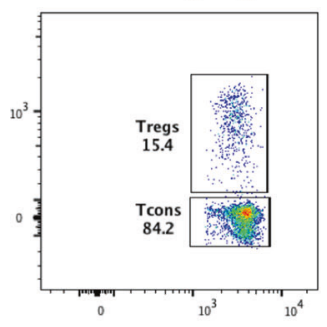

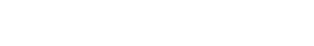

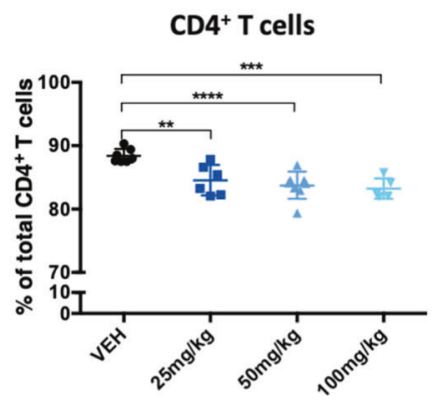

$\mathrm{CD4}^{+} \mathrm{T}$ cells

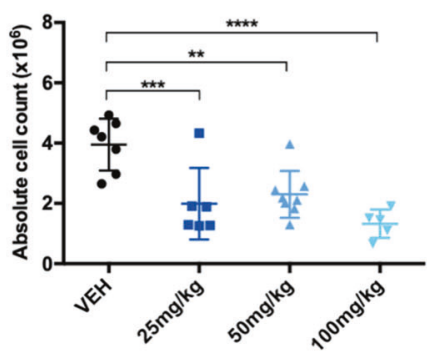

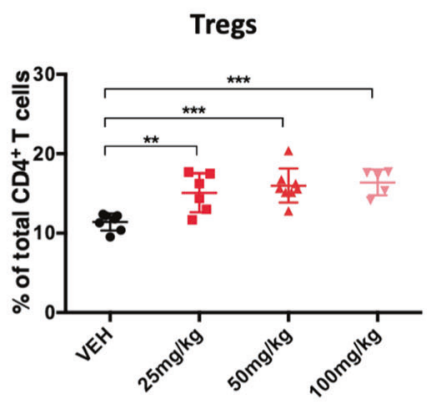

Tregs

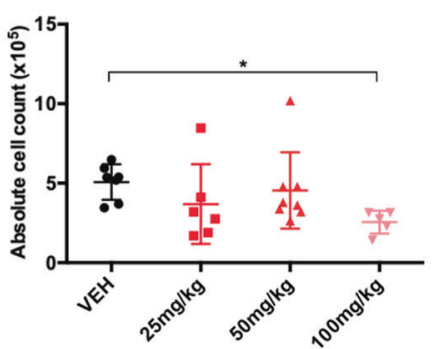

Fig. $2 \mathrm{CD8}^{+} \mathrm{T}$ cells, CD4 ${ }^{+} \mathrm{T}$ cells, and Tregs have distinctive sensitivity patterns to short-term in vivo treatment with venetoclax. FOXP3IRES-GFP mice were treated daily for 7 days with 25,50 , or $100 \mathrm{mg} / \mathrm{kg}$ venetoclax or vehicle control. A Representative flow plots of CD8 ${ }^{+}$ $\mathrm{T}$ cells, CD4 ${ }^{+} \mathrm{T}$ cells and Tregs from the spleens of mice treated with $100 \mathrm{mg} / \mathrm{kg}$ venetoclax compared to vehicle. B Percentage and C Absolute number of $\mathrm{CD}^{+} \mathrm{T}$ cells, $\mathrm{CD} 4^{+} \mathrm{T}$ cells, and Tregs isolated from the spleens of treated animals. $n \geq 5$ for each group of three independent experiments. Data represented as means \pm SEM. ${ }^{*} p<0.05$, ${ }^{* *} p<0.01$, ${ }^{* *} p<0.001$, ${ }^{* * *} p<0.0001$.

tolerated and resulted in a dose-dependent reduction in spleen and lymph node cellularity, white blood cells, lymphocytes, and reticulocytes, which was curious given that reticulocytes rely on $B C L-X_{L}$ for survival (Figs. S4, S5) [31]. Thymocyte subpopulations were similar in all animals apart from decreased $\mathrm{CD}^{+}$(single positive; SP) and $\mathrm{CD}^{-}{ }^{-} \mathrm{CD} 8^{-}$double negative (DN1) thymocytes at the highest dose (Fig. S6). $\mathrm{CD}^{+}{ }^{+} \mathrm{CD} 8^{+}$double positive (DP) thymocytes were unchanged supporting their reliance upon $B C L-X_{L}$ [32]. Although we focus on T cells, immunophenotypic analysis of other immune cells was also performed (Tables S1, S2). Of note, there appears to be greater sensitivity to venetoclax of $\mathrm{T}$ cells within the lymph nodes compared to those within the spleen or thymus. This is likely due to the increased proportion of naïve $T$ cells within the lymph nodes but differences in venetoclax bioavailability cannot be ruled out.

As predicted, based on our ex vivo studies, venetoclax led to significant dose-dependent decreases in the percentage and absolute number of $\mathrm{CD}^{+}$and $\mathrm{CD}^{+} \mathrm{T}$ cells while the percentage of Tregs increased (Fig. 2). One limitation to measuring changes in $\mathrm{T}$ cells ex vivo is the necessity to expand cells, leading to a universal effector memory-like phenotype [33-35]. To better assess $T$ cell sensitivity and adaptivity to venetoclax in surviving cells in vivo, we examined T cell subpopulations (Fig. 3). All naïve $\left(\mathrm{CD} 44^{\text {low }} \mathrm{CD} 2 \mathrm{~L}^{\text {high }}\right.$ ) and $\mathrm{CD}^{+}$and $\mathrm{CD}^{+}$central memory (CD44 ${ }^{\text {high }} \mathrm{CD} 62 \mathrm{~L}^{\text {high }}$ ) $\mathrm{T}$ cells were particularly sensitive to venetoclax indicating reliance on BCL-2 (Fig. 3B-D). As a result, effector memory (CD44 $\left.{ }^{\text {high }} \mathrm{CD} 62 \mathrm{~L}^{\text {low }}\right) \mathrm{T}$ cell numbers remained relatively stable and their relative percentages increased. While the majority of $\mathrm{CD}^{+}$and $\mathrm{CD}^{+} \mathrm{T}$ cells are naïve at steady state, Tregs were more equally distributed into naïve, central memory, and effector memory phenotypes (Fig. 3D). Thus, short-term venetoclax treatment in vivo causes significant changes in the global $\mathrm{T}$ cell landscape with relative sparing of all memory Tregs, which was likely partly responsible for their overall lower baseline sensitivity to venetoclax ex vivo (Fig. 1).

We next wanted to determine if the remaining $T$ cells following treatment adapted to $\mathrm{BCL}-2$ blockade similarly as when activated ex vivo (Fig. 1). While $B C L-2$ was significantly increased in all remaining $T$ cells, particularly in naïve cells, $B C L-X_{L}$ and $M C L-1$ levels also rose, especially in $\mathrm{CD}^{+}$and $\mathrm{CD} 4^{+} \mathrm{T}$ cells (Fig. 4). BIM levels either remained the same or decreased (Fig. 4). These results indicate that short-term venetoclax treatment alters the homeostatic $T$ cell landscape and differentially alters anti-apoptotic levels in $\mathrm{T}$ cells. 

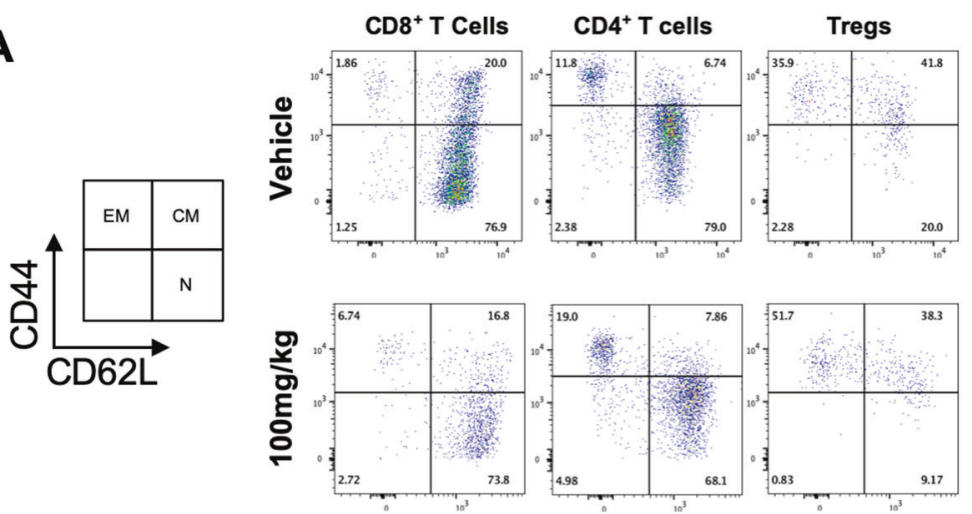

Naïve

\section{B}

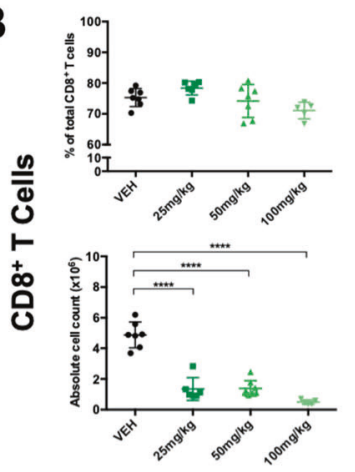

C

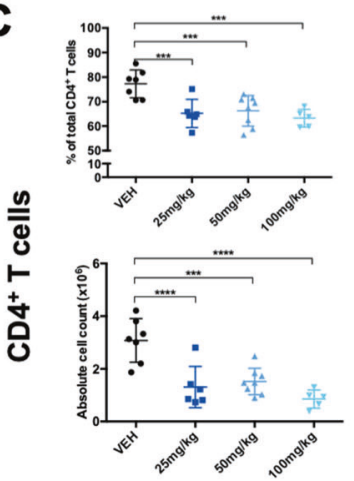

D

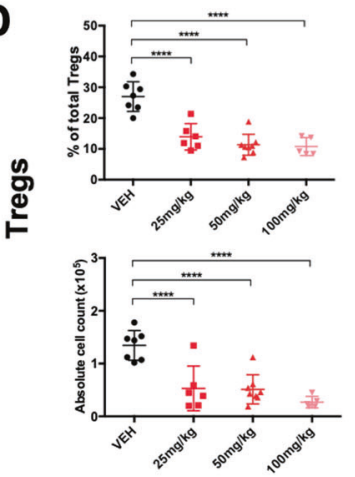

Central Memory
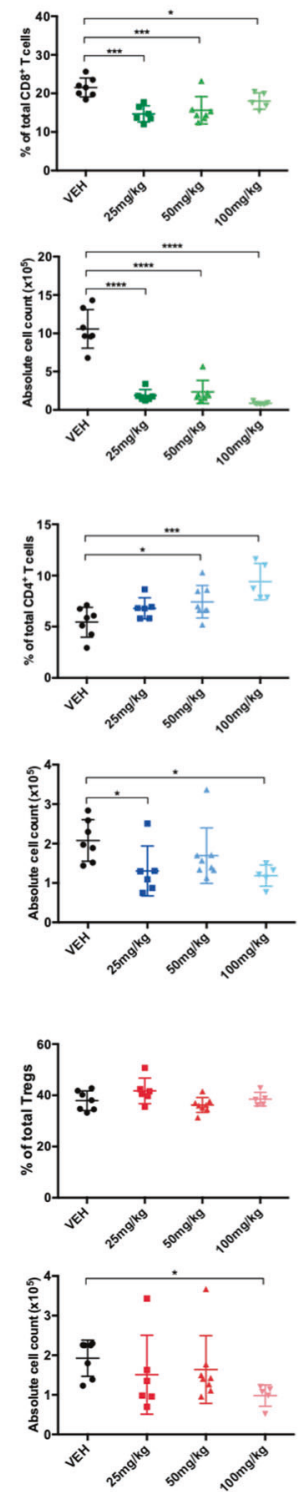

Effector Memory
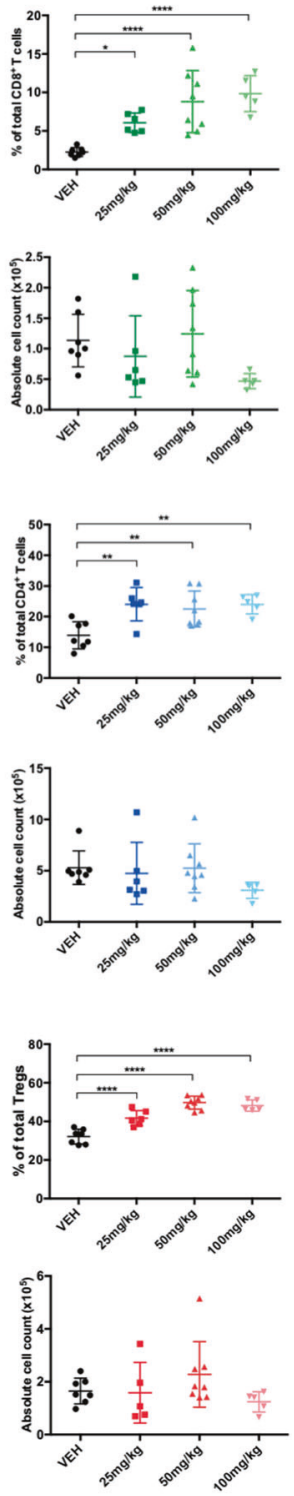

Fig. 3 Short-term in vivo treatment with venetoclax leads to an enrichment of effector memory cells in all three $T$ cell subsets. FOXP3IRES-GFP mice were treated daily for 7 days with increasing doses of venetoclax or vehicle control. A Representative gating strategy for CD8 ${ }^{+}$ $\mathrm{T}$ cells, CD4 ${ }^{+} \mathrm{T}$ cells, and Tregs from mice treated with $100 \mathrm{mg} / \mathrm{kg}$ venetoclax compared to vehicle. B-D Proportions of naive $\left(\mathrm{CD} 44^{\text {low }} \mathrm{CD} 62 \mathrm{~L}^{\text {high }}\right)$, effector memory $\left(\mathrm{CD} 44^{\text {high }} \mathrm{CD} 62 \mathrm{~L}^{\text {low }}\right)$, and central memory $\left(\mathrm{CD} 44^{\text {high }} \mathrm{CD} 62 \mathrm{~L}^{\text {high }}\right) \mathrm{T}$ cells, shown as percentages (top) and absolute numbers (bottom). B CD8 ${ }^{+}$T cells (C) $\mathrm{CD}^{+}$T cells (D) Tregs. $n \geq 5$ for each group. Data represented as means \pm SEM of three independent experiments. ${ }^{*} p<0.05,{ }^{* *} p<0.01,{ }^{* * *} p<0.001,{ }^{* * * *} p<0.0001$. 
BCL-X

MCL-1

BIM
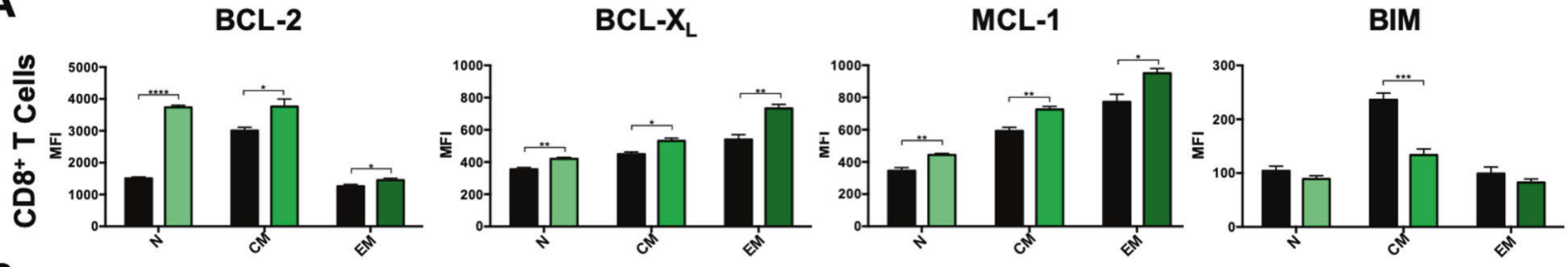

B
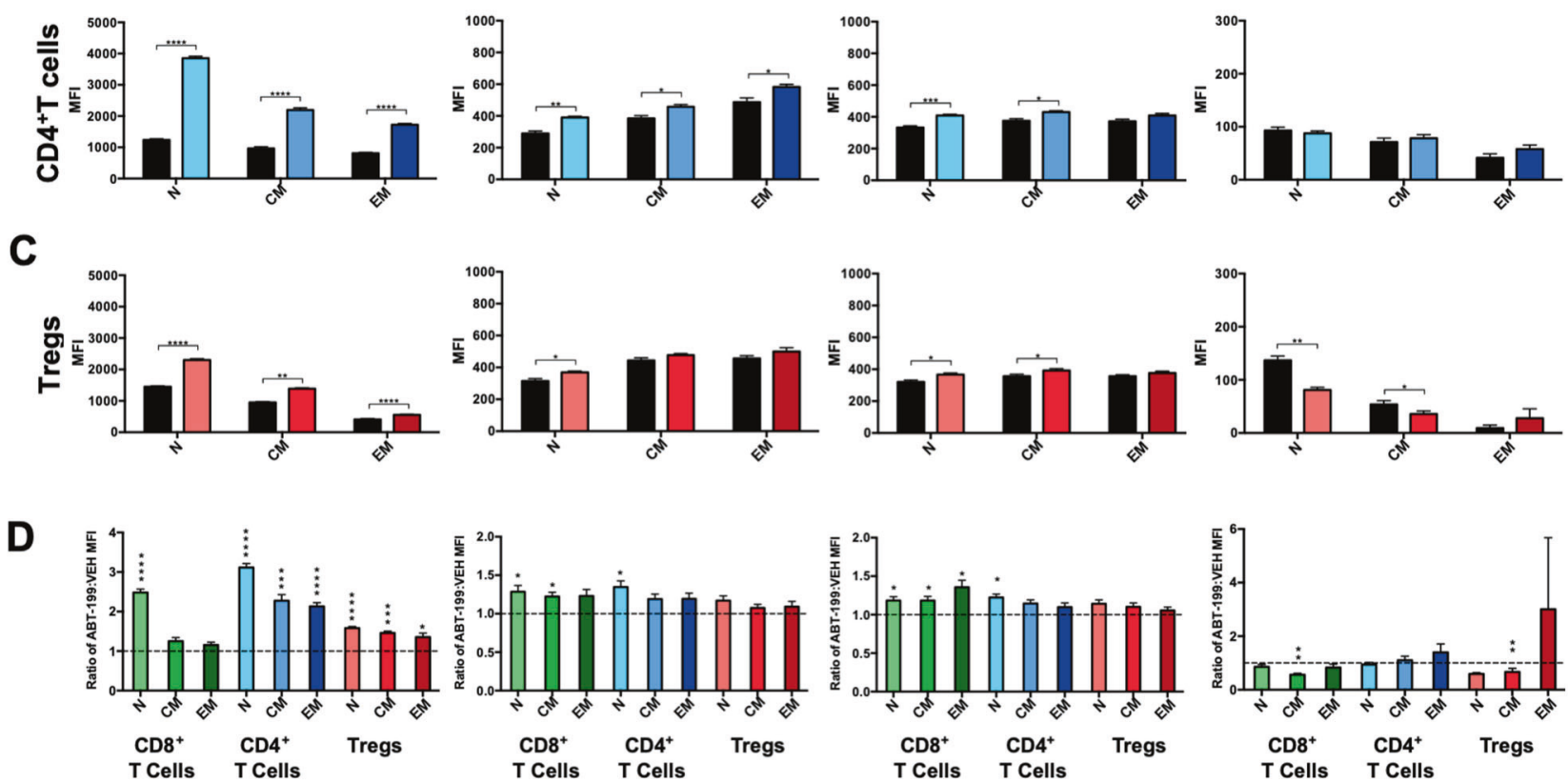

Fig. 4 Short-term in vivo treatment with venetoclax leads to an increase in anti-apoptotic protein levels, especially of BCL-2, in all three T cell subsets. FOXP3-IRES-GFP mice were treated daily for 7 days with $50 \mathrm{mg} / \mathrm{kg}$ venetoclax or vehicle control. Protein levels of key BCL-2 family members were measured in naïve, effector memory, and central memory subsets of $\mathbf{A ~ C D} 8^{+} \mathrm{T}$ cells, B CD4 ${ }^{+} \mathrm{T}$ cells, and C Tregs. Data is shown as mean fluorescence intensity. D Ratios of protein levels in T cells from venetoclax-treated animals compared to vehicle-treated controls. $n=$ 4 mice for each group. Data represented as means \pm SEM of three independent experiments. ${ }^{*} p<0.05,{ }^{* *} p<0.01,{ }^{* * *} p<0.001,{ }^{* * * *} p<0.0001$.

\section{T cells adapt to BCL-2 blockade through development to} maintain $\mathrm{T}$ cell homeostasis

We next tested if longer BCL-2 blockade would lead to similar phenotypic skewing and anti-apoptotic reprogramming in T cells akin to short-term treatment. To evaluate $T$ cells that have been equally treated, rather than a mix of variously aged cells, we utilized an autologous transplant model in which CD45.1 ${ }^{+}$mice were transplanted with T cell-depleted bone marrow from FOXP3IRES-GFP $\left(\mathrm{CD} 45.2^{+}\right)$mice and given vehicle, $25 \mathrm{mg} / \mathrm{kg}$, or $50 \mathrm{mg} /$ $\mathrm{kg}$ of venetoclax daily through day +28 post-transplant (Fig. $5 \mathrm{~A}$ ). Animals tolerated venetoclax but developed a slight dosedependent decrease in splenocytes, lymphocytes, and thymocytes extending 3 months post-transplant (Fig. S7). Despite these changes, mice showed no significant differences in the proportions of donor-derived $\mathrm{CD}^{+}, \mathrm{CD}^{+}$, or Treg cells immediately following treatment suggesting $T$ cell adaptivity (Figs. 5B, S8) [36]. However, there was a dose-dependent reduction in T cell numbers 2 and 3 months post-transplant, through the period of normal post-transplant homeostatic expansion (Fig. 5B) [37]. Despite this, the relative percentages of naïve, central memory, and effector memory $T$ cells were near normal immediately following treatment and beyond (Fig. $5 \mathrm{C}$ ). Similar to animals treated shortterm, venetoclax failed to induce major changes in thymocyte populations. However, treatment resulted in significant upregulation of $\mathrm{BCL}-2$, and to a lesser extent $\mathrm{BCL}-\mathrm{X}_{\mathrm{L}}$ and $\mathrm{MCL}-1$, in certain thymocytes (Fig. S9) [32]. These changes extended to mature T cells in treated animals (Fig. 6A). BIM expression was relatively stable in all $\mathrm{T}$ cells but was downregulated slightly in animals treated with $25 \mathrm{mg} / \mathrm{kg}$ and upregulated in those treated with $50 \mathrm{mg} / \mathrm{kg}$ indicating perhaps a biphasic, dose-dependent, response akin to what was measured following ex vivo expansion (Fig. 1). Despite increased levels of anti-apoptotic proteins and blocked $B C L-2$, venetoclax did not result in abnormal skewing of TCRV $\beta$ repertoires (Fig. S10). $C D 8^{+} \mathrm{T}$ cells from venetoclax-treated animals were significantly resistant to a wider range of $\mathrm{BCL}-2$ family-mediated cell death stimuli compared to $\mathrm{CD}^{+}{ }^{+} \mathrm{T}$ cells (Fig. 6B). Tregs were equally resistant to all stimuli whether or not they matured in the presence of venetoclax (Fig. 6B) [38]. The relative proportions of $\mathrm{CD} 4^{+}, \mathrm{CD}^{+}$, and Treg naive $\left(\mathrm{CD} 44^{\text {low }}\right)$ and memory (CD44 ${ }^{\text {high }}$ ) cells in each treatment condition were not significantly different, similar to what was measured in Fig. 5 (Fig. S11). Thereby, the cell death differences measured were not the result from selective depletion of naïve or memory cells. In conclusion, proportions of T cell subsets are unchanged secondary to long-term BCL-2 blockade post-transplant. However, such treatment induced significant long-lasting changes in BCL-2 family protein levels and cell death sensitivities, reflecting inherent differences between $T$ cells in their ability to acclimate to longterm BCL-2 blockade.

\section{Venetoclax leads to transcriptional alterations consistent with stimulated cells}

To determine if venetoclax led to changes beyond BCL-2 family protein levels we performed RNA sequencing on naïve $T$ cells immediately following treatment post-transplant. Indeed, venetoclax led to distinct transcriptional profiles for $\mathrm{CD}^{+}$and $\mathrm{CD}^{+}$ 
T cells as demonstrated by multidimensional principle component analysis (Fig. 7A). RNA-sequencing identified 143 and 501 differentially expressed genes with a significance cutoff of 0.01 FDR in $\mathrm{CD}^{+}$and $\mathrm{CD}^{+}{ }^{+}$cells respectively (Fig. S12A, B). $23 \%$ of differentially expressed genes were shared by $\mathrm{CD}^{+}$and $\mathrm{CD}^{+}$ $\mathrm{T}$ cells. Transcript levels of the two most important BCL-2 family regulators of $\mathrm{T}$ cell survival, $\mathrm{BCl}-2$ and $\mathrm{Bim}$, were significantly increased and decreased respectively in both $T$ cell subsets (Fig. 7B). However, the most significantly shared upregulated genes were those associated with T cell activation, including Irf4, Irf8, Batf, Cish, and Cd69 (Fig. S12C). Gene set enrichment analysis further determined that genes normally expressed in stimulated/

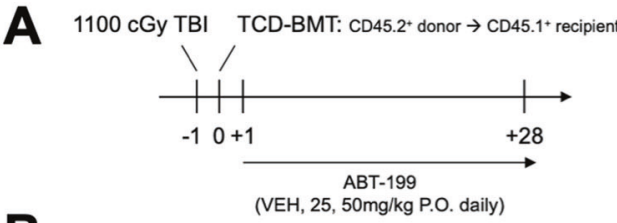

B
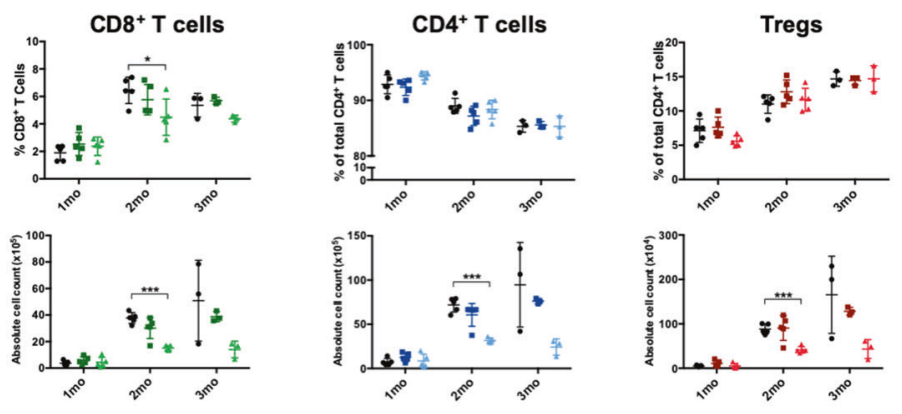

- VEH $=25 \mathrm{mg} / \mathrm{kg} \triangle 50 \mathrm{mg} / \mathrm{kg}$

- VEH $=25 \mathrm{mg} / \mathrm{kg}+50 \mathrm{mg} / \mathrm{kg}$

- VEH $=25 \mathrm{mg} / \mathrm{kg}+50 \mathrm{mg} / \mathrm{kg}$
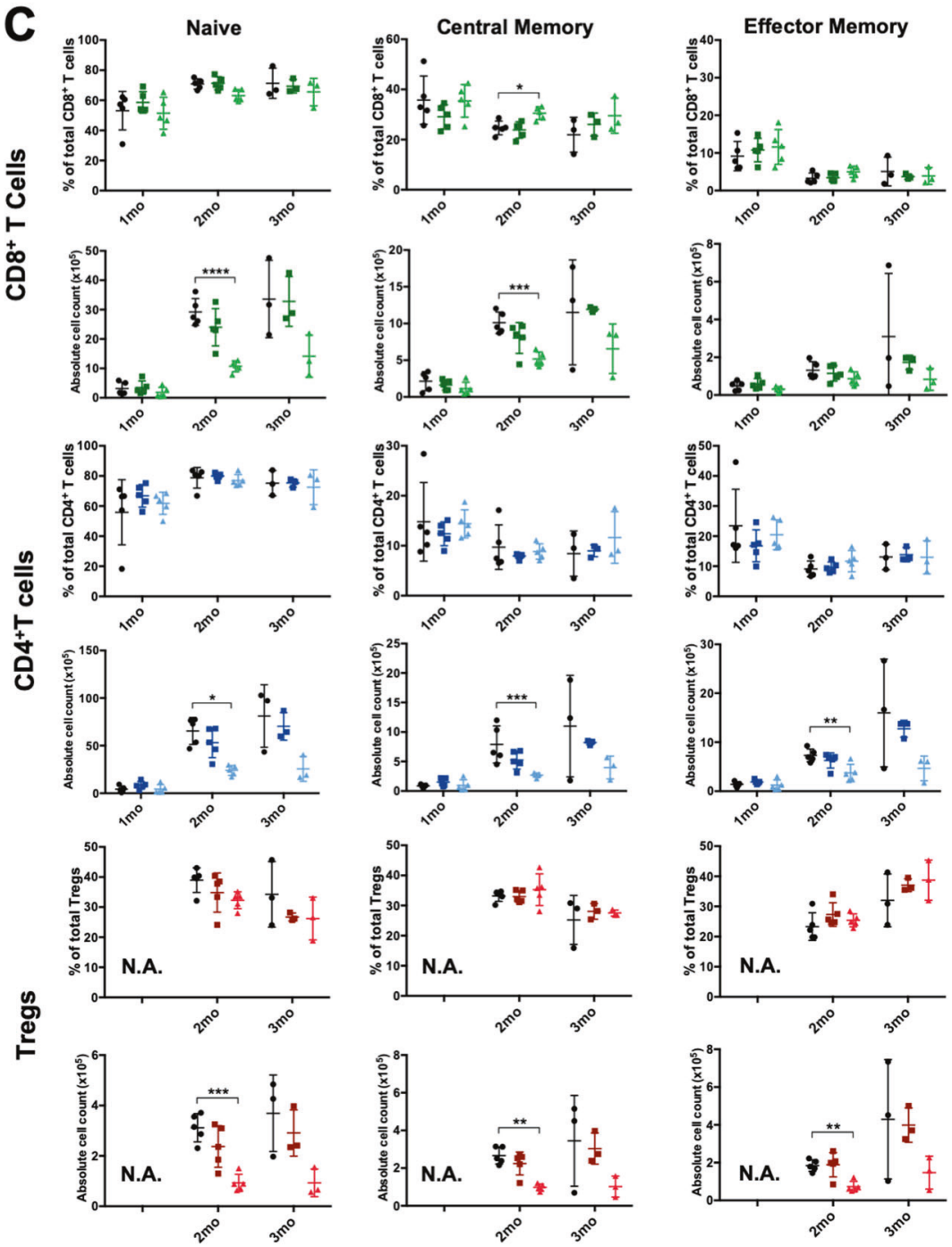
Fig. 5 Long-term in vivo treatment with venetoclax following bone marrow transplantation does not affect the relative proportions of any $T$ cell subset. A Schematic of transplant procedure where recipient CD45. $1^{+}$mice were lethally irradiated on day -1 and were transplanted with $2 \times 10^{6} \mathrm{~T}$ cell-depleted (TCD) bone marrow from FOXP3-IRES-GFP $\left(C D 45.2^{+}\right)$donors on day 0 . Daily oral gavage treatment with 25 or $50 \mathrm{mg} / \mathrm{kg}$ venetoclax was initiated on day +1 and continued until day +28 post-transplant. B Percentage (top) and absolute numbers (bottom) of $\mathrm{CD}^{+} \mathrm{T}$ cells, $\mathrm{CD} 4^{+} \mathrm{T}$ cells, and Tregs, shown as subsets of total $\mathrm{CD}^{+} \mathrm{T}^{-}$cells isolated from animals 1,2 , and 3 months posttransplant. C Proportions of naive (CD44 $\left.{ }^{\text {low }} \mathrm{CD} 62 \mathrm{~L}^{\text {high }}\right)$, effector memory (CD44 $\left.4^{\text {high }} \mathrm{CD} 62 \mathrm{~L}^{\text {low }}\right)$, and central memory $\left(\mathrm{CD} 44^{\text {high }} \mathrm{CD} 62 \mathrm{~L}^{\text {high }}\right) \mathrm{T}$ cells, shown as percentages (top) and absolute numbers (bottom). N.A. = the low number of Tregs one-month post-transplant precluded their thorough analysis at this time. $n=5$ mice/group for the 1 and 2 month timepoints and $n=3$ for the 3 month timepoint. Data represented as means \pm SEM of two independent experiments. ${ }^{*} p<0.05,{ }^{* *} p<0.01,{ }^{* *} p<0.001,{ }^{* * *} p<0.0001$.

A

BCL-2

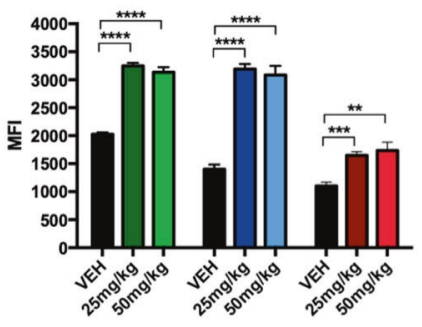

$B C L-X_{L}$

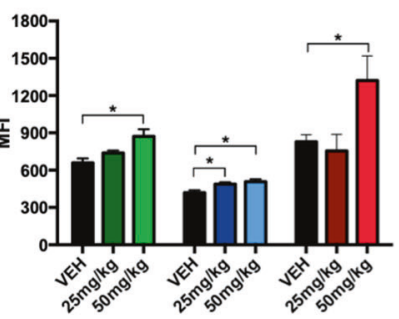

MCL-1

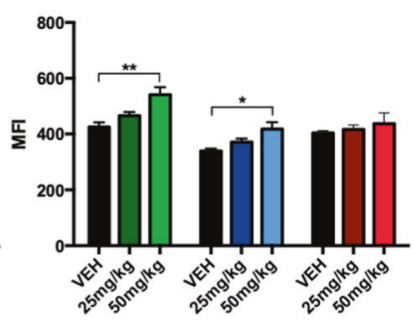

BIM

B
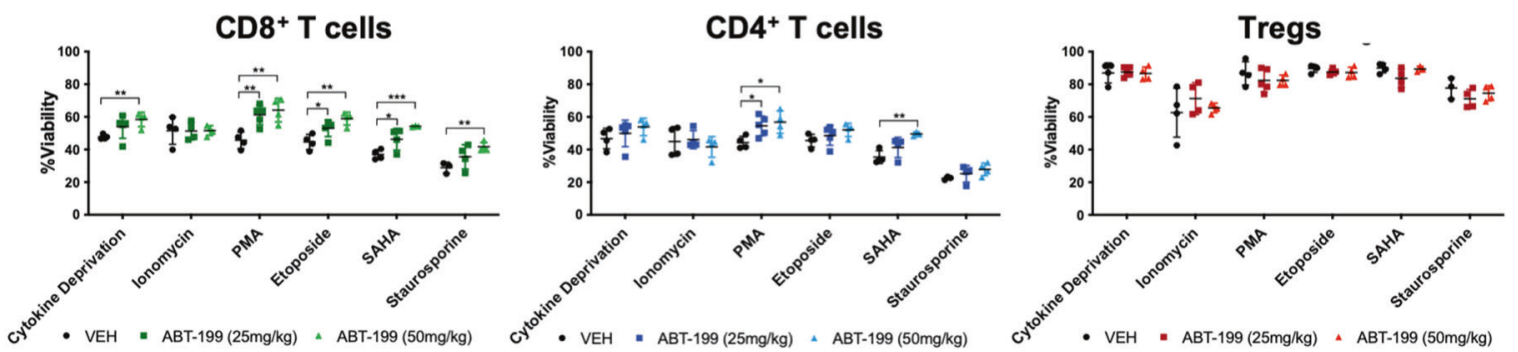

Fig. 6 Long-term in vivo treatment with venetoclax following bone marrow transplantation results in similar increases in BCL-2 levels but different cell death sensitivity between $\mathrm{T}$ cell subtypes. A Protein levels of naïve $\mathrm{CD} 8^{+} \mathrm{T}$ cells, $\mathrm{CD} 4^{+} \mathrm{T}$ cells and Tregs one-month posttransplant. $n \geq 3$ mice/group. B CD8 ${ }^{+}$T cells, CD4 ${ }^{+}$T cells, and Tregs from mice at the 2 month timepoint were treated with apoptotic stimuli for $24 \mathrm{~h}$. Viability of T cells was assessed by Annexin V/PI staining with Annexin $\mathrm{V}^{\text {neg }} \mathrm{PI}^{\text {neg }}$ cells considered viable. $n \geq 4$ mice/group. Data represented as means \pm SEM of two independent experiments. ${ }^{*} p<0.05,{ }^{* *} p<0.01,{ }^{* * *} p<0.001,{ }^{* * * *} p<0.0001$.

activated $\mathrm{T}$ cells were positively enriched in venetoclax-treated cells (Fig. 7C). Further analysis indicated similar altered pathways between $\mathrm{CD}^{+}$and $\mathrm{CD}^{+}{ }^{+}$cells suggesting a shared mechanism of action (Fig. 7D). There was most significant upregulation in genes associated with cell division and JAK/STAT signaling and downregulation in genes associated with MAPK and FoxO signaling. Thus, long-term BCL-2 blockade of $\mathrm{T}$ cells posttransplant during expansion not only changed their apoptotic rheostat, but also altered their global gene expression profiles to reflect an activated-like state.

\section{DISCUSSION}

It is well known that $\mathrm{T}$ cells have a shifting reliance on BCL-2 proteins during development, activation, contraction, and maintenance $[10,28,39]$. Much of what is known has been determined primarily through gene deletion animal models, while much less is understood on how $\mathrm{T}$ cells respond to anti-apoptotic targeting using $\mathrm{BH} 3$ mimetics. Our current study supports recent evidence that naïve $T$ cells are sensitive to short-term treatment with venetoclax $[4,5,40]$, and is the first to show that BCL-2 targeting in $\mathrm{CD}^{+}, \mathrm{CD}^{+}$, and Tregs in vitro and in vivo significantly and, rather uniformly, increase $\mathrm{BCL}-2, \mathrm{BCL}-\mathrm{X}_{\mathrm{L}}$, and $\mathrm{MCL}-1$ protein levels making these cells more resistant to cell death (Fig. 8). Because anti-apoptotic proteins in aggregate, and not alone, determine cell death sensitivity, our results point to differences between the ability of surviving T cells to acclimate or adapt to BCL-2 inhibition with venetocolax [41]. Interestingly, venetoclax-induced protein level changes were not solely due to increased transcription, suggesting that competition for and removal of endogenous $\mathrm{BH} 3-$ only proteins bound to BCL-2, such as BIM, may stabilize antiapoptotic proteins within $\mathrm{T}$ cells, similar to what has been observed for certain peptide and small molecule-based BH3mimetics in cancerous cells [42-44]. However, the exact mechanism(s) behind this are unknown and are currently being studied.

Overall, Tregs and $\mathrm{CD}^{+}{ }^{+} \mathrm{T}$ cells were more effective at adapting to $\mathrm{BCL}-2$ inhibition compared to $\mathrm{CD}^{+} \mathrm{T}$ cells both ex vivo and during short-term in vivo treatment (Fig. 8). The comparatively lower BCL-2 upregulation in Tregs was perhaps one reason why Tregs were not as affected by $\mathrm{BCL}-2$ targeting in vivo. Whether this is due to Tregs' lower dependency on BCL-2, greater dependency on MCL-1 at baseline, or that Tregs are able to more effectively modulate $\mathrm{BCL}-2$ protein family dependence against venetoclax is unclear $[40,45]$. Effector memory cells were resistant to venetoclax in all three $\mathrm{T}$ cell subsets, consistent with reports examining effector cells treated with ABT-737 and supporting that other antiapoptotic proteins are more pertinent for T cell survival during the transition from a naïve to a memory state, such as $M C L-1, B C L-X_{L}$, and $A 1$ [46-52]. Despite large changes in $T$ cell subsets in the periphery, thymocytes were only minimally affected by venetoclax 
treatment. Although BCL-2 is expressed at higher levels in DN and CD4 and CD8 SP cells, these cells are likely dependent on additional anti-apoptotic proteins such as $\mathrm{MCL}-1$ for their survival in this setting $[25,53]$.

Clinically however, patients are not given short bursts of venetoclax. Rather, they are treated with either single-agent venetoclax daily or following chemotherapy for up to 28 days as the marrow repopulates and the immune system homeostatically expands [54-59]. There are no studies of which we are aware that investigate how such treatment with venetoclax affects $T$ cell development. In this setting, although we found no reduction in T cell proportions following treatment, there was longer-lasting
A

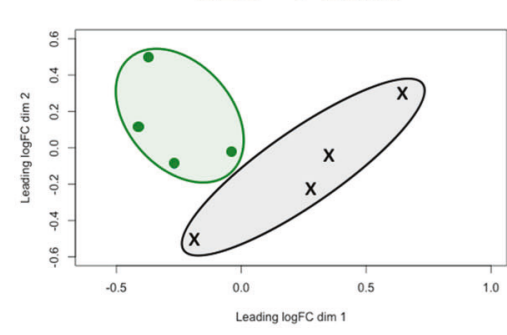

$\mathrm{CD}^{+} \mathrm{T}$ cells

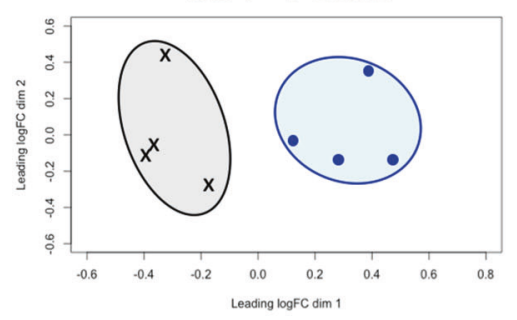

B
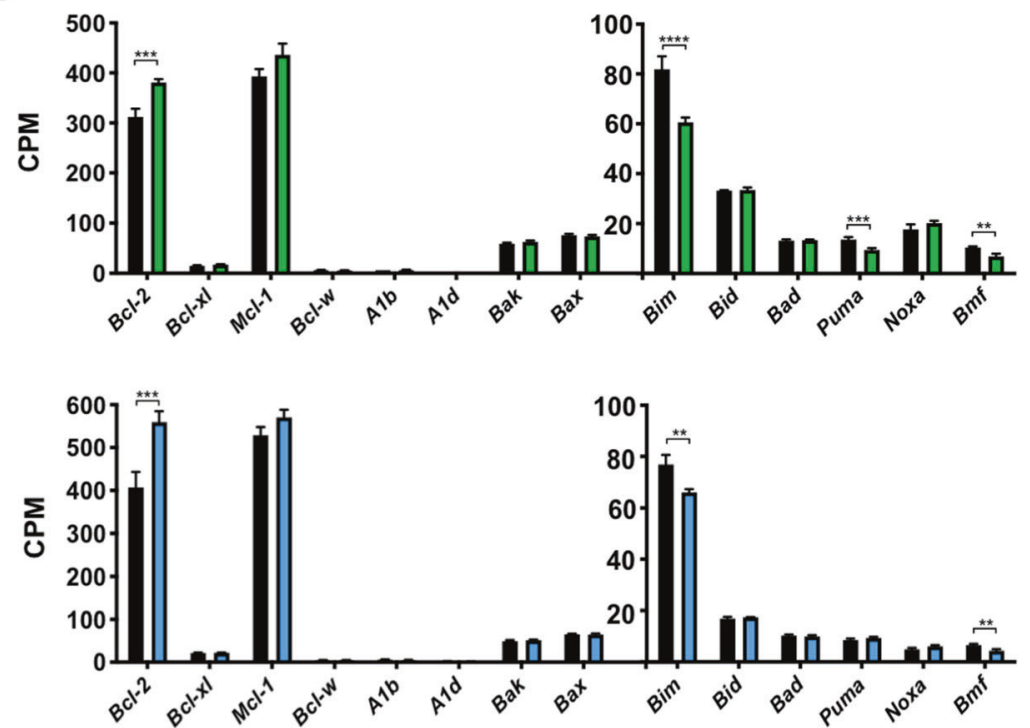

C

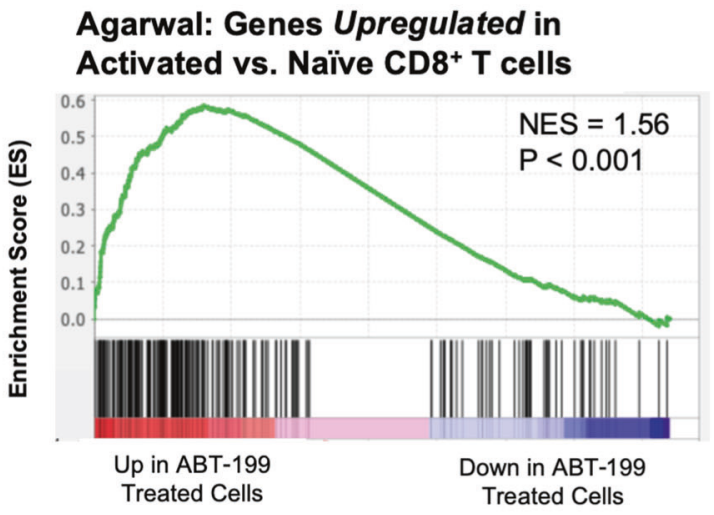

D

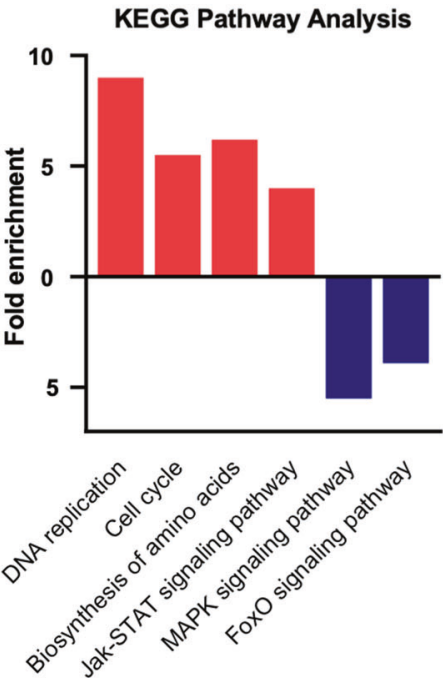

DNA Cell
Abbas: Genes Upregulated in Activated vs. Naïve $\mathrm{CD} 4^{+} \mathrm{T}$ cells

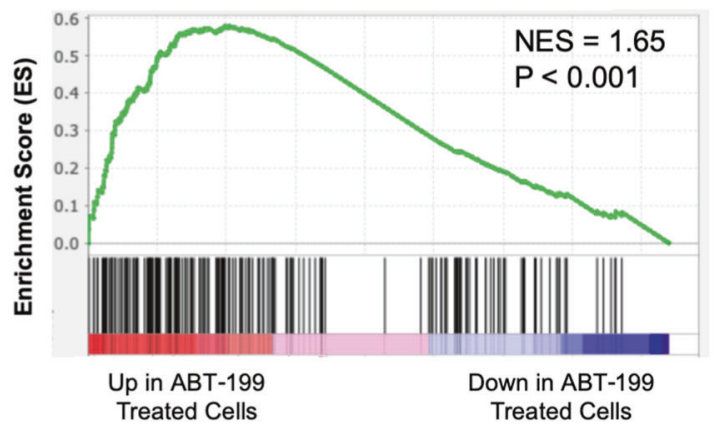
replication cycle

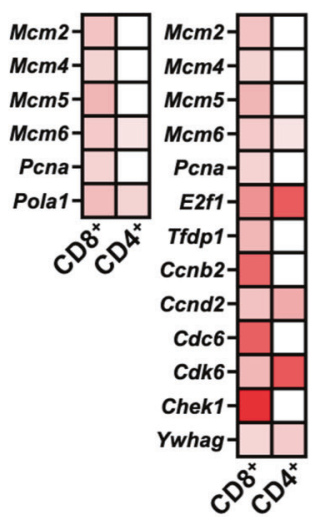

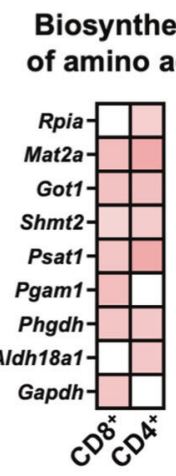

Jak-STAT

ds signaling

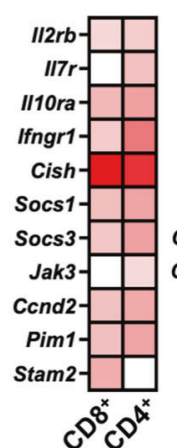

MAPK signaling
FoxO signaling 政 
Fig. 7 Long-term BCL-2 blockade leads to changes in BCL-2 family transcripts and upregulation of genes consistent with an activated phenotype. Mice were treated as described in Fig. 5 and naïve $\mathrm{CD} 8^{+}$and $\mathrm{CD} 4^{+} \mathrm{T}$ cells were collected for RNA-sequencing one day following the last dose of venetoclax. A Multidimensional principle component analysis of gene expression from $\mathrm{CD}^{+}$and $\mathrm{CD}^{+}{ }^{+}$isolated from venetoclax-treated (green and blue areas respectively) compared to vehicle-treated controls (black areas). B Counts per million reads (CPM) of the BCL-2 family genes, separated by multidomain anti-/pro-apoptotic and BH3-only proteins. C Gene set enrichment data of RNA-sequencing data performed using the 'Immunological Signatures' collection in the Molecular Signatures Database. Gene sets used were: GSE15930 for $\mathrm{CD}^{+} \mathrm{T}$ cell analysis [68] and GSE22886 for CD4 ${ }^{+} \mathrm{T}$ cell analysis [3]. D Transcriptional profiles of CD8 ${ }^{+}$and CD4 ${ }^{+} \mathrm{T}_{\text {cells by KEGG pathway }}$ analysis of significantly upregulated (red) and downregulated (blue) genes $(p<0.01)$. For all pathways enriched, individual genes are displayed in heatmap arrays according to fold change in expression normalized to vehicle with additional comparison between CD8 ${ }^{+}$and $\mathrm{CD}^{+} \mathrm{T}^{\mathrm{T}}$ cells within each panel. $n=4$ mice/group. ${ }^{*} p<0.05,{ }^{* *} p<0.01,{ }^{* * *} p<0.001,{ }^{* * *} p<0.0001$.

\section{T cell Landscape Changes in Remaining Cells}

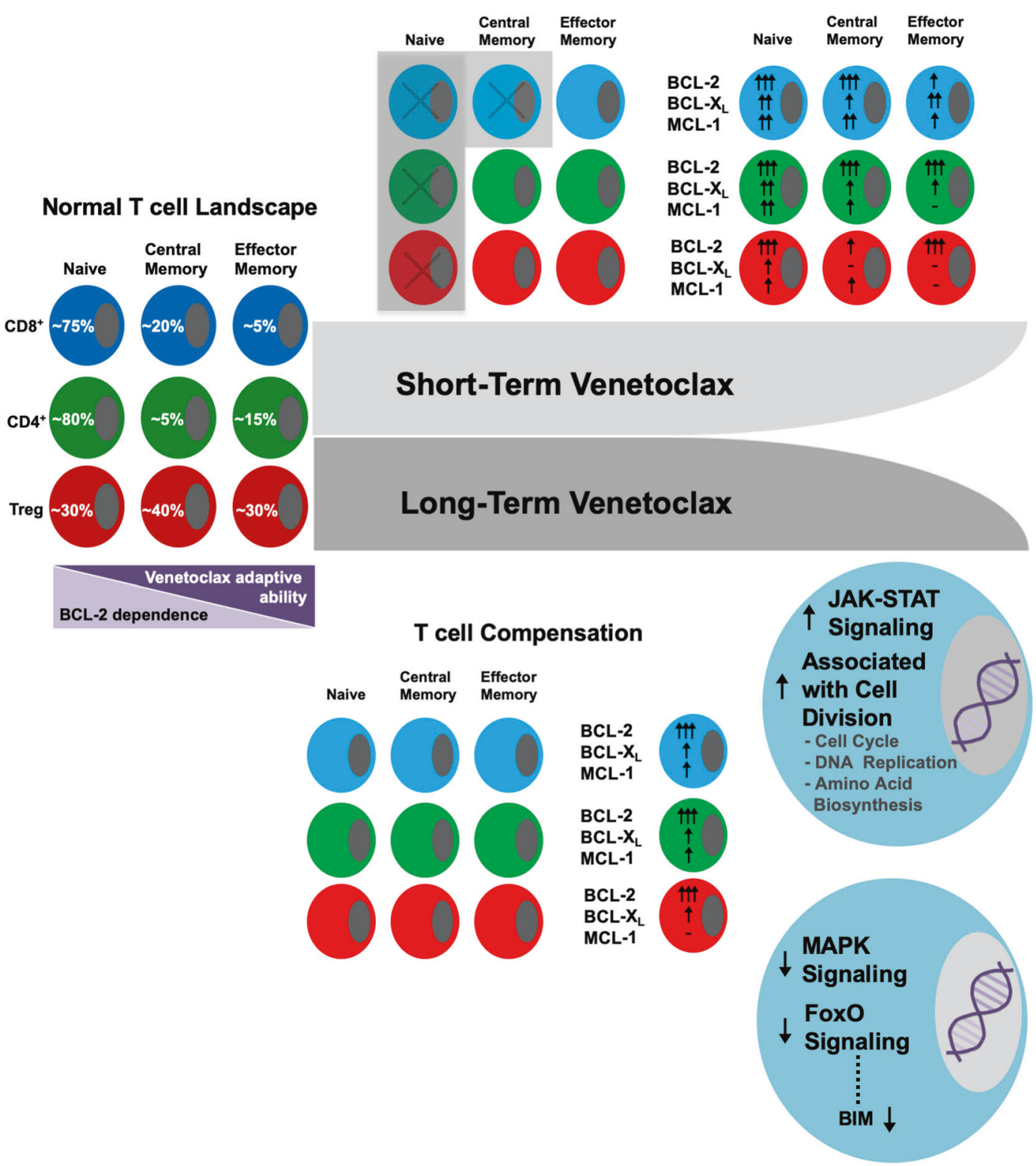

Fig. 8 Summary of differences in effects of short-term versus long-term venetoclax treatment in T cells. Normal percentages of naïve, central memory, and effector memory $\mathrm{CD}^{+}{ }^{+}, \mathrm{CD}_{4}{ }^{+}$, and Treg cells along with their respective cell death dependence on $\mathrm{BCL}-2$ and "adaptive" ability to alter anti-apoptotic dependency patterns in the setting of BCL-2 blockade is shown on the left. Short-term treatment with venetoclax alters the $\mathrm{T}$ cell landscape predominantly through killing most naïve $\mathrm{CD} 8^{+}, \mathrm{CD} 4^{+}$, and Treg cells and central memory $\mathrm{CD} 8^{+} \mathrm{T}$ cells. Surviving cells significantly upregulate BCL-2 protein expression. Surviving Tregs, on whole, do not alter their anti-apoptotic protein levels as much as $\mathrm{CD}^{+}$and $\mathrm{CD}^{+} \mathrm{T}$ cells. Long-term treatment with venetoclax, however, does not alter the relative percentages of $\mathrm{T}$ cell subtypes but does result in significantly increased BCL-2 protein expression in all T cells indicating BCL-2 family and T cell survival adaptation to BCL-2 blockade. Additionally, T cells treated long-term have significant changes in their mRNA expression patterns reflecting a more activated signature. 
lower cell numbers. While $\mathrm{CD}^{+} \mathrm{T}$ cells that matured in the presence of venetoclax had no survival disadvantage compared to other $\mathrm{T}$ cells, naïve $\mathrm{CD} 8^{+} \mathrm{T}$ cells and $\mathrm{CD} 4^{+} \mathrm{T}$ cells had increased levels of BCL-2 and were resistant to a range of apoptotic stimuli, indicating apoptotic adaptation. Again, the immediate and longerlasting BCL-2-associated changes between $\mathrm{CD}^{+}$and $\mathrm{CD}^{+}{ }^{+} \mathrm{T}$ cells suggest that they uniquely adapt, akin to differences we previously measured in T cells lacking Bim [11]. These results emphasize that the context in which the BCL-2 family of proteins are targeted may greatly affect $T$ cell death sensitivity, similar to what has been measured in BCL-2 family genetic deletion models $[10,11]$. How these changes relate to immune function in patients is currently unknown. Intriguingly, recent reports of two clinical trials where venetoclax was given for 21 and 28 days at $400 \mathrm{mg}$ and $800 \mathrm{mg}$ daily respectively found increased infections/sepsis in patients who received venetoclax, yet there were no differences in lymphopenia between those patients receiving placebo or the higher dose venetoclax $[54,60]$. One speculation was that venetoclax-induced unknown functional effects on lymphocytes [60].

Changes in $\mathrm{T}$ cells treated with venetoclax through development were not limited to the BCL-2 family. There was shared significant downregulation of Jun subfamilies (c-Jun, JunB, JunD) and c-Fos, genes which encode proteins critical for $T$ cell function through their interaction with NFAT to bind AP-1 regulatory elements [61-63]. AP-1 (Fos/Jun) activity is controlled in large part by MAP kinases and genes within the MAPK signaling pathway, which were significantly downregulated in treated naïve $\mathrm{CD}^{+}$ and $\mathrm{CD}^{+}{ }^{\mathrm{T}}$ cells. How these genetic changes are related to $\mathrm{BCL}-2$ inhibition and affect $T$ cell function or metabolism is unclear and an area we are currently investigating. Additionally, whether venetoclax induces genetic "adaptation" versus particular T cell apoptotic selection (i.e. naïve T cell killing) followed by expansion of this specific T cell subgroup is currently unknown. This along with downregulation of FoxO and upregulation of Jak-STAT signaling may be responsible for the recently reported increased efficacy of tumor specific $C D 8^{+}$effector $\mathrm{T}$ cells in mice treated with venetoclax daily for 14 days and even more robustly in combination with anti-PD-1/PD-L1 blockade [4]. Verma et al. [64] also found that inhibition of the MAPK signaling pathway through MEK1/2 inhibition induces strong anti-tumor activity and reprogramming of effector $\mathrm{CD}^{+} \mathrm{T}$ cells. Additionally, FoxO target genes are involved in cell cycle and apoptotic control and directly regulate the expression of $\operatorname{Bim}[65,66]$. Downregulation of this pathway may have been responsible for the decrease in Bim expression in venetoclax-treated cells and may be related to the upregulation of genes associated with cell cycle, DNA replication, and amino acid biosynthesis. It is unclear why the larger $(50 \mathrm{mg} /$ $\mathrm{kg}$ ) dose of venetoclax decreased Bim mRNA expression but resulted in slightly increased BIM protein in bulk $\mathrm{CD}^{+}$and $\mathrm{CD} 4^{+}$ $T$ cells post-transplant. While the majority of these cells were naïve, it is possible that memory cells played a role in this increase. In conclusion, while there is evidence that genetic changes occur in direct response to venetoclax treatment in cancer cells, our study is the first to show that venetoclax also imparts genetic reprogramming in normal $T$ cells [67]. The durability of these changes is an area of active investigation.

Our results highlight the dynamism and adaptive capabilities of $T$ cells in response to BCL-2 inhibition and how such treatment, either for short or long periods of time, reshapes the immune system. Future studies are aimed at determining the mechanism responsible for the genetic changes found in $T$ cells following BCL-2-blockade and how these affect immune functionality in various scenarios. We also believe that further exploration is warranted into how venetoclax and other BH3-mimetics may affect other immune cells, particularly in the context of anticancer therapy, for which these agents are currently being studied and used clinically.

\section{DATA AVAILABILITY}

All RNA-sequencing data are uploaded to the NCBI GEO database under the accession number GSE164483.

\section{REFERENCES}

1. Hanahan D, Weinberg RA. Hallmarks of cancer: the next generation. Cell. 2011;144:646-74.

2. Opferman JT. Attacking cancer's Achilles heel: antagonism of anti-apoptotic BCL2 family members. FEBS J. 2016;283:2661-75.

3. Abbas AR, Baldwin D, Ma Y, Ouyang W, Gurney A, Martin F, et al. Immune response in silico (IRIS): immune-specific genes identified from a compendium of microarray expression data. Genes Immun. 2005;6:319-31.

4. Kohlhapp FJ, Haribhai D, Mathew R, Duggan R, Ellis PA, Wang R, et al. Venetoclax increases intra-tumoral effector $T$ cells and anti-tumor efficacy in combination with immune checkpoint blockade. Cancer Discov. 2020;11:68-79.

5. Rohner L, Reinhart R, lype J, Bachmann S, Kaufmann T, Fux M. Impact of BH3mimetics on human and mouse blood leukocytes: a comparative study. Sci Rep. 2020;10:222.

6. Khaw SL, Merino D, Anderson MA, Glaser SP, Bouillet P, Roberts AW, et al. Both leukaemic and normal peripheral $B$ lymphoid cells are highly sensitive to the selective pharmacological inhibition of prosurvival Bcl-2 with ABT-199. Leukemia. 2014;28:1207-15.

7. Wojciechowski S, Tripathi P, Bourdeau T, Acero L, Grimes HL, Katz JD, et al. Bim/ $\mathrm{Bcl}-2$ balance is critical for maintaining naive and memory $\mathrm{T}$ cell homeostasis. J Exp Med. 2007;204:1665-75.

8. Gabriel SS, Bon N, Chen J, Wekerle T, Bushell A, Fehr T, et al. Distinctive expression of $\mathrm{Bcl}-2$ factors in regulatory $\mathrm{T}$ cells determines a pharmacological target to induce immunological tolerance. Front Immunol. 2016;7:73.

9. Ludwig LM, Nassin ML, Hadji A, LaBelle JL. Killing two cells with one stone: pharmacologic BCL-2 family targeting for cancer cell death and immune modulation. Front Pediatr. 2016:4:135.

10. Renault $\Pi$, Chipuk JE. Getting away with murder: how does the BCL-2 family of proteins kill with immunity? Ann N. Y Acad Sci. 2013;1285:59-79.

11. Ludwig LM, Roach LE, Katz SG, LaBelle JL. Loss of BIM in T cells results in BCL-2 family $\mathrm{BH} 3$-member compensation but incomplete cell death sensitivity normalization. Apoptosis. 2020;25:247-60.

12. Haribhai D, Lin W, Relland LM, Truong N, Williams CB, Chatila TA. Regulatory $T$ cells dynamically control the primary immune response to foreign antigen. J Immunol. 2007;178:2961-72.

13. LaBelle JL, Katz SG, Bird GH, Gavathiotis E, Stewart ML, Lawrence C, et al. A stapled BIM peptide overcomes apoptotic resistance in hematologic cancers. J Clin Invest. 2012;122:2018-31.

14. Ludwig LM, Maxcy KL, LaBelle JL. Flow cytometry-based detection and analysis of BCL-2 family proteins and mitochondrial outer membrane permeabilization (MOMP). Methods Mol Biol. 2019;1877:77-91.

15. Yardeni $T$, Eckhaus $M$, Morris HD, Huizing $M$, Hoogstraten-Miller S. Retro-orbital injections in mice. Lab Anim. 2011;40:155-60.

16. Faber AC, Farago AF, Costa C, Dastur A, Gomez-Caraballo M, Robbins $R$, et al. Assessment of ABT-263 activity across a cancer cell line collection leads to a potent combination therapy for small-cell lung cancer. Proc Natl Acad Sci USA 2015;112:E1288-1296.

17. Tse C, Shoemaker AR, Adickes J, Anderson MG, Chen J, Jin S, et al. ABT-263: a potent and orally bioavailable Bcl-2 family inhibitor. Cancer Res. 2008;68:3421-8.

18. Pitter K, Bernal F, Labelle J, Walensky LD. Dissection of the BCL-2 family signaling network with stabilized alpha-helices of $\mathrm{BCL}-2$ domains. Methods Enzymol. 2008;446:387-408.

19. Robinson MD, McCarthy DJ, Smyth GK. edgeR: a Bioconductor package for differential expression analysis of digital gene expression data. Bioinformatics. 2010;26:139-40.

20. Subramanian A, Tamayo P, Mootha VK, Mukherjee S, Ebert BL, Gillette MA, et al. Gene set enrichment analysis: a knowledge-based approach for interpreting genome-wide expression profiles. Proc Natl Acad Sci USA. 2005;102:15545-50.

21. Huang da W, Sherman BT, Lempicki RA. Systematic and integrative analysis of large gene lists using DAVID bioinformatics resources. Nat Protoc. 2009;4:44-57.

22. Huang da W, Sherman BT, Lempicki RA. Bioinformatics enrichment tools: paths toward the comprehensive functional analysis of large gene lists. Nucleic Acids Res. 2009;37:1-13.

23. Carrington EM, Zhan Y, Brady JL, Zhang JG, Sutherland RM, Anstee NS, et al. Antiapoptotic proteins $B C L-2, M C L-1$ and $A 1$ summate collectively to maintain survival of immune cell populations both in vitro and in vivo. Cell Death Differ 2017;24:878-88.

24. Boise LH, Minn AJ, Noel PJ, June CH, Accavitti MA, Lindsten T, et al. CD28 costimulation can promote $\mathrm{T}$ cell survival by enhancing the expression of $\mathrm{BCl}-\mathrm{XL}$. Immunity. 1995;3:87-98. 
25. Opferman JT, Letai A, Beard C, Sorcinelli MD, Ong CC, Korsmeyer SJ. Development and maintenance of $B$ and $T$ lymphocytes requires antiapoptotic MCL-1. Nature. 2003;426:671-6.

26. Gomez J, Martinez AC, Gonzalez A, Garcia A, Rebollo A. The Bcl-2 gene is differentially regulated by IL-2 and IL-4: role of the transcription factor NF-AT. Oncogene. 1998;17:1235-43.

27. Lord JD, McIntosh BC, Greenberg PD, Nelson BH. The IL-2 receptor promotes proliferation, $\mathrm{bcl}-2$ and $\mathrm{bcl}-\mathrm{x}$ induction, but not cell viability through the adapter molecule Shc. J Immunol. 1998;161:4627-33.

28. Carrington EM, Tarlinton DM, Gray DH, Huntington ND, Zhan Y, Lew AM. The life and death of immune cell types: the role of $\mathrm{BCL}-2$ anti-apoptotic molecules. Immunol Cell Biol. 2017;95:870-7.

29. Hildeman D, Jorgensen T, Kappler J, Marrack P. Apoptosis and the homeostatic control of immune responses. Curr Opin Immunol. 2007;19:516-21.

30. Wang X, Szymczak-Workman AL, Gravano DM, Workman CJ, Green DR, Vignali DA. Preferential control of induced regulatory $\mathrm{T}$ cell homeostasis via a $\mathrm{Bim} / \mathrm{Bcl}-2$ axis. Cell Death Dis. 2012;3:e270.

31. Grillot DA, Merino R, Nunez G. Bcl-XL displays restricted distribution during T cell development and inhibits multiple forms of apoptosis but not clonal deletion in transgenic mice. J Exp Med. 1995;182:1973-83.

32. Chonghaile TN, Roderick JE, Glenfield C, Ryan J, Sallan SE, Silverman LB, et al. Maturation stage of T-cell acute lymphoblastic leukemia determines $\mathrm{BCL}-2$ versus $B C L-X L$ dependence and sensitivity to ABT-199. Cancer Discov. 2014;4:1074-87.

33. Neeson $P$, Shin A, Tainton KM, Guru P, Prince HM, Harrison SJ, et al. Ex vivo culture of chimeric antigen receptor $T$ cells generates functional CD8 $+\mathrm{T}$ cells with effector and central memory-like phenotype. Gene Ther. 2010;17:1105-16.

34. Xu Y, Zhang M, Ramos CA, Durett A, Liu E, Dakhova O, et al. Closely related T-memory stem cells correlate with in vivo expansion of CAR.CD19-T cells and are preserved by IL-7 and IL-15. Blood. 2014;123:3750-9.

35. Yang S, Gattinoni L, Liu F, Ji Y, Yu Z, Restifo NP, et al. In vitro generated anti-tumor $T$ lymphocytes exhibit distinct subsets mimicking in vivo antigen-experienced cells. Cancer Immunol Immunother. 2011;60:739-49.

36. Auletta JJ, Devecchio JL, Ferrara JL, Heinzel FP. Distinct phases in recovery of reconstituted innate cellular-mediated immunity after murine syngeneic bone marrow transplantation. Biol Blood Marrow Transpl. 2004;10:834-47.

37. Porter $\mathrm{DL}$, June $\mathrm{CH}$. T-cell reconstitution and expansion after hematopoietic stem cell transplantation: 'T' it up! Bone Marrow Transpl. 2005;35:935-42.

38. Happo L, Strasser A, Cory S. BH3-only proteins in apoptosis at a glance. J Cell Sci. 2012;125:1081-7.

39. Strasser A. The role of BH3-only proteins in the immune system. Nat Rev Immunol. 2005;5:189-200.

40. Carrington EM, Vikstrom IB, Light A, Sutherland RM, Londrigan SL, Mason KD, et al. $\mathrm{BH} 3$ mimetics antagonizing restricted prosurvival $\mathrm{BCl}-2$ proteins represent another class of selective immune modulatory drugs. Proc Natl Acad Sci USA. 2010;107:10967-71.

41. Merino D, Giam M, Hughes PD, Siggs OM, Heger K, O'Reilly LA, et al. The role of $\mathrm{BH} 3$-only protein Bim extends beyond inhibiting $\mathrm{Bcl}$-2-like prosurvival proteins. J Cell Biol. 2009;186:355-62.

42. Caenepeel S, Brown SP, Belmontes B, Moody G, Keegan KS, Chui D, et al. AMG 176 , a selective mcl1 inhibitor, is effective in hematologic cancer models alone and in combination with established therapies. Cancer Discov. 2018;8:1582-97.

43. Hadji A, Schmitt GK, Schnorenberg MR, Roach L, Hickey CM, Leak LB, et al. Preferential targeting of MCL-1 by a hydrocarbon-stapled BIM BH3 peptide. Oncotarget. 2019;10:6219-33.

44. Kotschy A, Szlavik Z, Murray J, Davidson J, Maragno AL, Le Toumelin-Braizat G, et al. The MCL1 inhibitor $\mathrm{S} 63845$ is tolerable and effective in diverse cancer models. Nature. 2016;538:477-82.

45. Pierson W, Cauwe B, Policheni A, Schlenner SM, Franckaert D, Berges J, et al. Antiapoptotic Mcl-1 is critical for the survival and niche-filling capacity of Foxp3 (+) regulatory T cells. Nat Immunol. 2013;14:959-65.

46. Cippa PE, Kraus AK, Lindenmeyer MT, Chen J, Guimezanes A, Bardwell PD, et al. Resistance to ABT-737 in activated T lymphocytes: molecular mechanisms and reversibility by inhibition of the calcineurin-NFAT pathway. Cell Death Dis. 2012;3: e299.

47. Koenen P, Heinzel S, Carrington EM, Happo L, Alexander WS, Zhang JG, et al. Mutually exclusive regulation of $T$ cell survival by IL-7R and antigen receptorinduced signals. Nat Commun. 2013;4:1735.

48. Kurtulus $\mathrm{S}$, Tripathi $\mathrm{P}$, Moreno-Fernandez ME, Sholl $\mathrm{A}$, Katz JD, Grimes $\mathrm{HL}$, et al. $\mathrm{Bcl}-2$ allows effector and memory CD8 $+\mathrm{T}$ cells to tolerate higher expression of Bim. J Immunol. 2011;186:5729-37.

49. Tripathi $\mathrm{P}$, Koss $\mathrm{B}$, Opferman JT, Hildeman DA. Mcl-1 antagonizes Bax/Bak to promote effector $\mathrm{CD} 4(+)$ and $\mathrm{CD} 8(+)$ T-cell responses. Cell Death Differ. 2013:20:998-1007.
50. Tripathi $P$, Mitchell TC, Finkelman F, Hildeman DA. Cutting edge: limiting amounts of IL-7 do not control contraction of CD4+ T cell responses. J Immunol. 2007; 178:4027-31.

51. Verschelde C, Walzer T, Galia P, Biemont MC, Quemeneur L, Revillard JP, et al. A1/ Bfl-1 expression is restricted to TCR engagement in T lymphocytes. Cell Death Differ. 2003;10:1059-67.

52. Wensveen FM, van Gisbergen KP, Derks IA, Gerlach C, Schumacher TN, van Lier $\mathrm{RA}$, et al. Apoptosis threshold set by Noxa and Mcl-1 after T cell activation regulates competitive selection of high-affinity clones. Immunity. 2010;32:754-65.

53. Dzhagalov I, Dunkle A, He YW. The anti-apoptotic Bcl-2 family member $\mathrm{Mcl}-1$ promotes T lymphocyte survival at multiple stages. J Immunol. 2008;181:521-8.

54. DiNardo CD, Pratz K, Pullarkat V, Jonas BA, Arellano M, Becker PS, et al. Venetoclax combined with decitabine or azacitidine in treatment-naive, elderly patients with acute myeloid leukemia. Blood. 2019;133:7-17.

55. Guerra VA, DiNardo C, Konopleva M. Venetoclax-based therapies for acute myeloid leukemia. Best Pract Res Clin Haematol. 2019;32:145-53.

56. Jain N, Keating $M$, Thompson P, Ferrajoli A, Burger J, Borthakur G, et al. Ibrutinib and venetoclax for first-line treatment of CLL. New Engl J Med. 2019;380:2095-103.

57. Konopleva M, Pollyea DA, Potluri J, Chyla B, Hogdal L, Busman T, et al. Efficacy and biological correlates of response in a phase II study of venetoclax monotherapy in patients with acute myelogenous leukemia. Cancer Discov. 2016;6:1106-17.

58. Shahswar R, Beutel G, Klement P, Rehberg A, Gabdoulline R, Koenecke C, et al. FLA-IDA salvage chemotherapy combined with a seven-day course of venetoclax (FLAVIDA) in patients with relapsed/refractory acute leukaemia. $\mathrm{Br} J$ Haematol. 2020;188:e11-e15.

59. Thol F, Ganser A. Treatment of relapsed acute myeloid leukemia. Curr Treat Options Oncol. 2020;21:66.

60. Kumar SK, Harrison SJ, Cavo M, de la Rubia J, Popat R, Gasparetto C, et al. Venetoclax or placebo in combination with bortezomib and dexamethasone in patients with relapsed or refractory multiple myeloma (BELLINI): a randomised, double-blind, multicentre, phase 3 trial. Lancet Oncol. 2020;21:1630-42.

61. Atsaves V, Leventaki V, Rassidakis GZ, Claret FX. AP-1 transcription factors as regulators of immune responses in cancer. Cancers. 2019;11:1037.

62. Chen L, Glover JN, Hogan PG, Rao A, Harrison SC. Structure of the DNA-binding domains from NFAT, Fos and Jun bound specifically to DNA. Nature. 1998;392:42-48.

63. Rao A, Luo C, Hogan PG. Transcription factors of the NFAT family: regulation and function. Annu Rev Immunol. 1997;15:707-47.

64. Verma $V$, Jafarzadeh $N$, Boi $S$, Kundu $S$, Jiang $Z$, Fan $Y$, et al. MEK inhibition reprograms $\mathrm{CD} 8(+) \mathrm{T}$ lymphocytes into memory stem cells with potent antitumor effects. Nat Immunol. 2021;22:53-66.

65. Peng SL. Foxo in the immune system. Oncogene. 2008;27:2337-44.

66. Stahl M, Dijkers PF, Kops GJ, Lens SM, Coffer PJ, Burgering BM, et al. The forkhead transcription factor FoxO regulates transcription of p27Kip1 and Bim in response to IL-2. J Immunol. 2002;168:5024-31.

67. Zhao X, Ren Y, Lawlor M, Shah BD, Park PMC, Lwin T, et al. BCL2 amplicon loss and transcriptional remodeling drives ABT-199 resistance in b cell lymphoma models. Cancer Cell. 2019:35:752-766 e759.

68. Agarwal P, Raghavan A, Nandiwada SL, Curtsinger JM, Bohjanen PR, Mueller DL, et al. Gene regulation and chromatin remodeling by IL-12 and type I IFN in programming for CD8 $\mathrm{T}$ cell effector function and memory. J Immunol. 2009;183:1695-704.

\section{ACKNOWLEDGEMENTS}

The authors thank Pieter Faber and the High Throughput Genomics Core Facility, David Leclerc in the Flow Cytometry Facility, and the Comparative Pathology Core Facility for special assistance and services. The authors thank John Cao for assistance with sequencing pipeline analysis, Eric E. Smith for graphics support, and Tamar Uziel for scientific input and discussion. This work was supported by grants from the AbbVie-University of Chicago Collaborative (JLL), The Comer Developmental Board (JLL), Jill and John Svoboda (JLL and LML), The Rizzo Family Foundation (JLL and LML), Catherine and Donald Kleinmuntz (JLL), and the University of Chicago MSTP training grant/NIH T32GM007281 (DBB).

\section{AUTHOR CONTRIBUTIONS}

LML performed and conceived the experiments, analyzed data, prepared figures, and wrote the manuscript. $\mathrm{KMH}$ helped perform animal experiments and analyze data. $\mathrm{DBB}$ and $\mathrm{ATT}$ analyzed data and prepared figures. BRB and MEM conceived experiments, analyzed data, and helped prepare the manuscript. JDL conceived 
experiments and edited manuscript. JLL conceived the experiments, analyzed data, prepared figures, and wrote the final manuscript.

\section{ETHICAL APPROVAL}

All animal experiments were approved by and performed in accordance with the guidelines and regulations set forth by the Institutional Animal Care and Use Committee of the University of Chicago. This study did not involve human subjects, data, or tissue.

\section{COMPETING INTERESTS}

The authors declare no competing financial interests. JLL received research funding from a combined AbbVie-University of Chicago research collaboration. BRB receives remuneration as an advisor to Magenta Therapeutics and BlueRock Therapeutics, research funding from BlueRock Therapeutics, Rheos Medicines, Childrens' Cancer Research Fund, and KidsFirst Fund, and is a co-founder of Tmunity. JDL is an employee of AbbVie Inc.

\section{ADDITIONAL INFORMATION}

Supplementary information The online version contains supplementary material available at https://doi.org/10.1038/s41419-021-04285-4.
Correspondence and requests for materials should be addressed to James L. LaBelle.

Reprints and permission information is available at http://www.nature.com/ reprints

Publisher's note Springer Nature remains neutral with regard to jurisdictional claims in published maps and institutional affiliations.

(c) (i)

Open Access This article is licensed under a Creative Commons Attribution 4.0 International License, which permits use, sharing, adaptation, distribution and reproduction in any medium or format, as long as you give appropriate credit to the original author(s) and the source, provide a link to the Creative Commons license, and indicate if changes were made. The images or other third party material in this article are included in the article's Creative Commons license, unless indicated otherwise in a credit line to the material. If material is not included in the article's Creative Commons license and your intended use is not permitted by statutory regulation or exceeds the permitted use, you will need to obtain permission directly from the copyright holder. To view a copy of this license, visit http://creativecommons. org/licenses/by/4.0/.

(c) The Author(s) 2021 